\title{
Review \\ Extracellular Matrix-Based Biomaterials for Cardiovascular Tissue Engineering
}

\author{
Astha Khanna ${ }^{1}$, Maedeh Zamani ${ }^{2,3}$ and Ngan F. Huang $2,3,4,5, *$ (D) \\ 1 Graver Technologies, Newark, NJ 07105, USA; akhanna@gravertech.com \\ 2 Department of Cardiothoracic Surgery, Stanford University, Stanford, CA 94305, USA; maedeh@stanford.edu \\ 3 Stanford Cardiovascular Institute, Stanford University, Stanford, CA 94305, USA \\ 4 Department of Chemical Engineering, Stanford University, Stanford, CA 94305, USA \\ 5 Veterans Affairs Palo Alto Health Care System, Palo Alto, CA 94304, USA \\ * Correspondence: ngantina@stanford.edu
}

Citation: Khanna, A.; Zamani, M.; Huang, N.F. Extracellular Matrix-Based Biomaterials for Cardiovascular Tissue Engineering. J. Cardiovasc. Dev. Dis. 2021, 8, 137. https://doi.org/10.3390/jcdd8110137

Academic Editor: Felix B. Engel

Received: 30 August 2021

Accepted: 19 October 2021

Published: 22 October 2021

Publisher's Note: MDPI stays neutral with regard to jurisdictional claims in published maps and institutional affiliations.

Copyright: (c) 2021 by the authors. Licensee MDPI, Basel, Switzerland. This article is an open access article distributed under the terms and conditions of the Creative Commons Attribution (CC BY) license (https:// creativecommons.org/licenses/by/ $4.0 /)$.

\begin{abstract}
Regenerative medicine and tissue engineering strategies have made remarkable progress in remodeling, replacing, and regenerating damaged cardiovascular tissues. The design of threedimensional (3D) scaffolds with appropriate biochemical and mechanical characteristics is critical for engineering tissue-engineered replacements. The extracellular matrix (ECM) is a dynamic scaffolding structure characterized by tissue-specific biochemical, biophysical, and mechanical properties that modulates cellular behavior and activates highly regulated signaling pathways. In light of technological advancements, biomaterial-based scaffolds have been developed that better mimic physiological ECM properties, provide signaling cues that modulate cellular behavior, and form functional tissues and organs. In this review, we summarize the in vitro, pre-clinical, and clinical research models that have been employed in the design of ECM-based biomaterials for cardiovascular regenerative medicine. We highlight the research advancements in the incorporation of ECM components into biomaterial-based scaffolds, the engineering of increasingly complex structures using biofabrication and spatial patterning techniques, the regulation of ECMs on vascular differentiation and function, and the translation of ECM-based scaffolds for vascular graft applications. Finally, we discuss the challenges, future perspectives, and directions in the design of next-generation ECM-based biomaterials for cardiovascular tissue engineering and clinical translation.
\end{abstract}

Keywords: tissue engineering; regenerative medicine; extracellular matrix (ECM)

\section{Introduction}

Vascular diseases such as atherosclerosis, aortic aneurysm, and peripheral arterial disease are a major cause of mortality and loss of quality of life [1]. The replacement of damaged or diseased vasculature with engineered substitutes is a rapidly advancing pursuit of researchers in the field of vascular tissue engineering and regenerative medicine. One of the challenges is to engineer three-dimensional (3D) vascular tissues that have structural integrity and that support physiological function [2]. Extracellular matrix (ECM) is secreted by cells and is composed of structural and regulatory proteins and polysaccharides. Each organ and tissue is composed of a distinct ECM with respect to its biochemical composition and structural organization. In particular, the vascular ECM consists of biomolecules such as collagen, laminin, fibronectin, elastin, and heparan sulfate proteoglycans [3]. The ECM regulates many cellular functions such as proliferation, migration, and differentiation [3]. Since ECM-based biomaterials can mimic the composition and structure of the ECM, they are attractive biomaterials for repairing or restoring damaged organs and tissues. The ECM plays a vital role in vascular tissue engineering by providing both a physical scaffold for structural integrity and 3D shape, as well as relaying intrinsic biochemical and mechanical cues that regulate cellular function. 
There has been tremendous progress in the field of vascular tissue engineering and regenerative medicine in the past decades, notably with the development of biomaterials derived from ECM proteins that provide mechanical support and biochemical signals that modulate vascular cell attachment, phenotype, and behavior. ECM-derived biomaterials were initially used as two-dimensional (2D) coatings for the improved cell adhesion to tissue culture polystyrene dishes. Later advancements led to three-dimensional (3D) ECMderived biomaterials with improved tunability to recapitulate the dynamics, composition, and structure of the native ECM [4].

Vascular cells are responsive to the ECM in a process known as dynamic reciprocity [5] or bi-directional cross talk between the cells and their environment [6-8], which is accompanied by the continuous and dynamic remodeling of the ECM [9] into tissue-specific 3D architectures and compositions. In turn, the ECM sends mechanical and biochemical cues to the resident vascular lineages through the engagement of cell-surface receptors, the activation of intracellular signaling cascades, and the intrinsic changes in gene expression and cell phenotype [2,6]. The synthesis and secretion of ECM molecules by vascular lineages in physiological and pathological [10] conditions regulates numerous biological processes, including vascular differentiation [11,12], angiogenesis [10,13], and wound healing [14-16]. By virtue of its evolutionary conserved composition and its impact on embryonic development, cellular, and organ homeostasis, the ECM constitutes an ideal substrate to promote the repair of damaged or diseased tissue, and also as serves as a scaffold for engineering whole tissues and organs. The past decade has had remarkable progress towards the next generation of ECM-based biomaterials, including advancements in the isolation and characterization of ECM components, as well as the development of decellularization techniques to preserve native mammalian structure and composition.

In this review, we highlight major developments in biomaterials derived from mammalian ECM in the field of vascular tissue engineering and regenerative medicine, with a focus on translational applications. We also discuss the efficacy of ECM-derived biomaterials to regenerate and repair tissues, along with the progression of therapies from in vitro to preclinical studies, and ultimately towards clinical translation.

\section{Overview of the Vasculature}

The human circulatory system consists of a sophisticated network of blood and lymphatic vessels that transport fluids throughout the body $[17,18]$. Each level of hierarchy plays an important role in maintaining homeostasis throughout the body. Large vessels such as arteries and veins conduct the transport of large volumes of blood between organ systems. Large vessels progress into smaller vessels to control blood pressure and volumetric flow to the cells and tissues in an organ. Large and small vessels work together to maintain homeostasis throughout the body. Capillaries are the smallest and most densely distributed vessels, and they have a specialized role of directly exchanging fluid with cells in the tissues, as well as being involved in lymphocyte migration and homing [17-19]. The distribution and orientation of the microvasculature is influenced by the metabolic activity of the specific tissue [20].

The anatomy of large and small vessel differs in structure and function (Figure 1) [20,21]. Large vessels (i.e., arteries and veins) are composed of three layers: an inner layer composed of endothelium; middle layer formed by smooth muscle cells, elastic tissue, and collagen fibers; and outer layer composed of elastic tissue and collagen fibers [22]. The percentage of elastic tissue in the arteries in considerably higher than veins because arteries transport blood at higher pressures [23]. Small vessels (i.e., arterioles, venules, and capillaries) are narrower and thinner than large vessels and participate in blood perfusion. Capillaries are the smallest vessels and are one-cell thick to allow mass exchange and fluid permeability. The cellular structure of large and small vessels is also distinctive. Arteries, veins and arterioles are composed of endothelial cells (ECs), smooth muscle cells (SMCs), and pericytes [24]. Venules are made of ECs, pericytes, and SMCs that differ in vessel 
thickness that than arterioles $[25,26]$. Capillaries are composed of a single layer of ECs and pericytes [19].

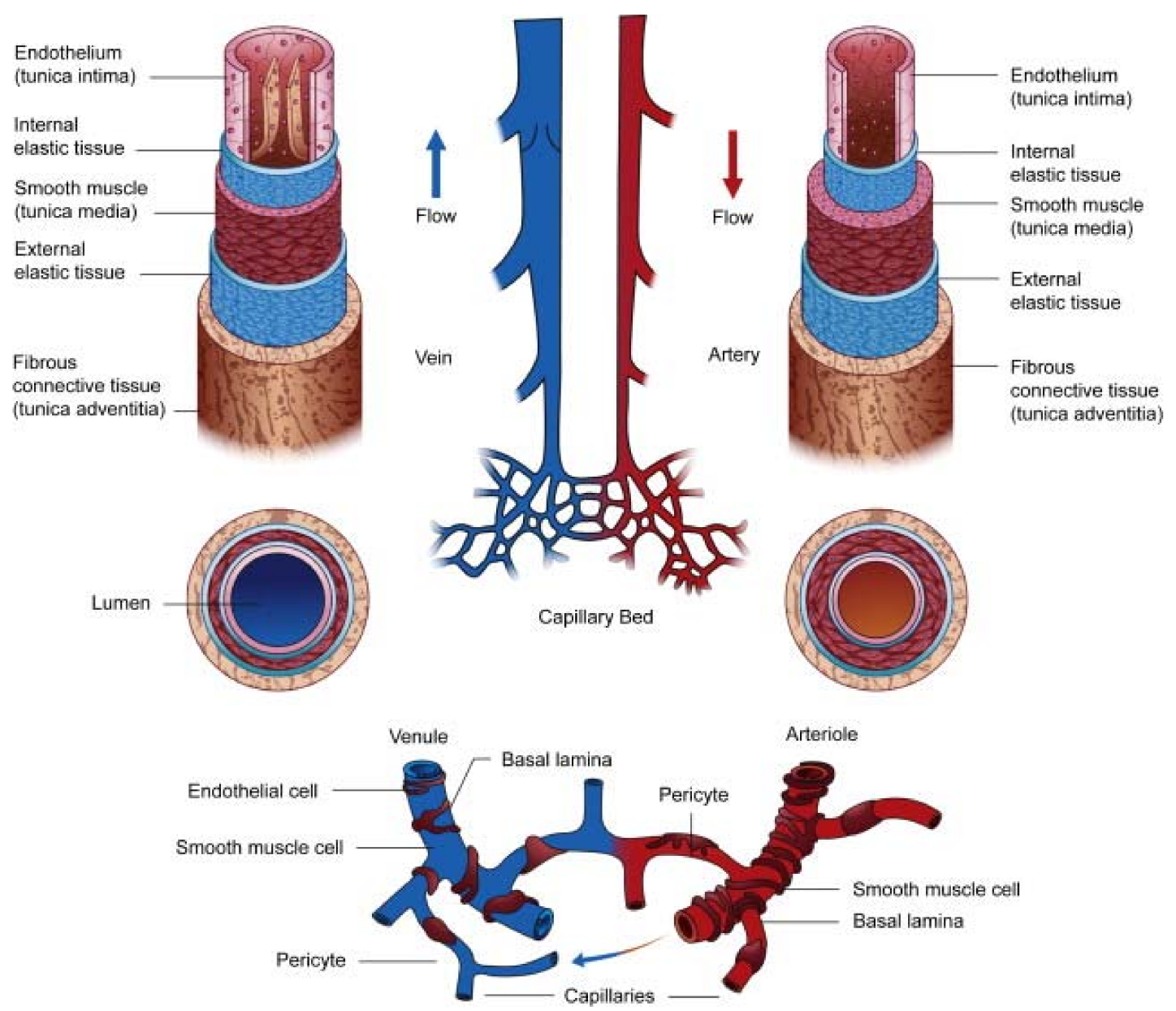

Figure 1. Anatomy of large and small blood vessels. Reprinted from Stratman et al. [21]. “Chapter 24-Blood Vessel Formation" from Principles of Developmental Genetics (Second Edition), with permission from Elsevier.

ECs form the innermost layer of the vasculature. These cells are highly polarized in which their luminal side is exposed to blood circulation, while their basal side is anchored to basal membrane produced by ECs themselves. ECs are responsible for vasomotion (i.e., contraction-relaxation of vessel wall) by secretion of vasoactive cytokines and response to circulatory vasomotion mediators. ECs also play a vital role in thromboregulation, inflammatory responses, and vascular permeability [27]. Vascular SMCs are predominantly responsible for maintaining the integrity of the vessel and providing mechanical support for contraction. These cells are actively involved in the secretion of ECM components, including collagens, elastins, and proteoglycans [28]. Similarly, pericytes are perivascular cells that wrap around vessels and play an SMC-like role in stabilizing the vasculature, while also contributing to angiogenesis [29].

Despite the difference in the structural and functional aspect of various blood vessels, the ECMs found in blood vessels generally consist of a similar ECM composition. The ECMs in the basement membrane upon which the ECs reside include laminin, collagen IV, nidogen, and heparan sulfate proteoglycan [30]. The combination of the biochemical and physical cues, provided by the self-assembled layer of proteins that form the basement membrane, are major elements of the vascular EC microenvironment [30]. The basement membrane compliance and topography are intrinsic attributes of the EC microenvironment [30]. Besides the ECMs found in the basement membrane, the ECMs found 
in other parts of blood vessels include elastin that provides elasticity and collagen for structural integrity.

\section{ECM-Based Biomaterials}

The vascular system performs a critical role in maintaining homeostasis by carrying out the transport of oxygen, nutrients, blood cells, and hormones through continuous blood circulation in the body. Blood is transported to all parts of the body through blood vessels. Owing to these specialized functions of the vasculature, vascular biomaterials should exhibit characteristics of tissue resilience and structural mimicry, while supporting cellular function. There has been tremendous progress in the production of ECM-based biomaterials in the past two decades. Numerous studies [31,32] have utilized the components of native ECMs as a hydrogel for efficient encapsulation, while providing tissue-like water content.

To modulate mechanical properties of ECM-based hydrogels, various physical and chemical crosslinking methods have been employed. Physical crosslinking approaches such as ionic interaction (crosslinking between two molecules with opposite charges), hydrogen bonding, thermal induction-mediated solid-to-gel phase transition, and chemical approaches (i.e., photo-polymerization, enzymatic crosslinking) have been employed [33]. Crosslinking conditions such as light exposure sites, intensities, and periods can modulate the mechanical properties of ECM-based hydrogels [34,35].

Among physical crosslinking approaches, hydrogels are ionically crosslinked under mild temperature and physiological $\mathrm{pH}$ conditions [36]. Hydrophobic interactions result in polymer swelling by water uptake that forms the hydrogel. Alginate, a polysaccharide derived from seaweed, can be crosslinked at room temperature and physiological $\mathrm{pH}$, making it a frequently used ECM for the encapsulation of living cells [37]. Polysaccharides such as chitosan and dextran have been used to produce hydrogels by hydrophobic interactions [36]. In another example, freeze/thaw temperature change induce the formation of poly (vinyl alcohol) (PVA) hydrogel through the formation of PVA crystallites that act as crosslinking sites in the network [37]. Additionally, poly(acrylic acid) and poly (methacrylic acid) form a complex with polyethylene glycol (PEG) by hydrogen bonding as a result of the $\mathrm{pH}$ dependent swelling of the gels [38]. Capello and collaborators employed protein interactions to crosslink silk-like and elastin-like block co-polymers using hydrogen-bonded beta sheets or strands. A major advantage of physical crosslinking methods is the absence of harsh reagents that supports cellular encapsulation within the hydrogel, but a disadvantage is the limited range in the hydrogel's mechanical strength.

Aside from physical crosslinking methods, chemical crosslinking such as chain growth polymerization (free radical, cationic or anionic) involves the processes of initiation, propagation and termination. Radical polymerization of low molecular weight monomers in the presence of crosslinking agents can be used to product chemically crosslinked gels. For example, poly(2-hydroxyethylmethacrylate) (pHEMA) hydrogels are formed by polymerization of HEMA in the presence of crosslinking agents such as ethylene glycol dimethacrylate [39]. For example, Sperinde et al. employed transglutaminase to synthesize PEG-based hydrogels [40]. Although chemical crosslinking is versatile and can be used to product hydrogels with good mechanical stability, the crosslinking agents can be toxic compounds and can react with the bioactive compounds to product adverse reactions. This is avoided in the physically crosslinked gels. The incorporation of other ECM components can also be used to enhance the mechanical integrity of ECM hydrogels such as network formation between individual ECM components (i.e., collagen/fibrin [41,42], fibrin/HA [43], collagen/chondroitin sulfate/ hyaluronic acid (HA)) [44]. The incorporation of ECM components has not only been shown to enhance mechanical integrity, but it also modulates cellular behavior such as in the upregulation of tissue specific gene expression and ECM molecule secretion [43-45].

Commonly, ECMs are isolated from human or animal tissues [46]. A popular method for biopharmaceutical application is recombinant protein secretion using Chinese hamster ovary cells [47]. These artificial or ECM-like proteins are of great interest in biomaterial 
scaffolds as they can have a specific sequence and a defined molecular weight $[48,49]$. Additionally, owing to the popularity of basement membrane ECM derived from EngelbrethHolm-Swarm (EHS) mouse sarcoma cells, some ECMs can also be isolated from this basement membrane matrix. Finally, ECMs can also be derived by decellularization of tissues for subsequent recellularization. The properties and in vitro applications of common ECMbased biomaterials such as collagen, elastin, and decellularized ECM are described below.

Collagen: Collagen is the most abundant structural protein in the mammalian ECM that imparts tensile strength to prevent deformation of tissue [50]. Collagen provides mechanical integrity to the vasculature and other biological tissues. Structurally, collagen is composed of three parallel polypeptide strands that form a triple helix, and the arrangement of varying polypeptide strands lead to a large number of isoforms. Among them, collagen I and collagen III isoforms are found in the tunica media and tunica adventitia, respectively. Collagen-based biomaterials can be developed using several strategies. Among them, collagen can be purified from common tissue sources such as calf skin or rat tail to form a functional scaffold. Alternatively, collagen-based scaffolds derived from decellularized matrix preserve the original tissue shape and ECM structure.

Collagen-based biomaterials from extracted collagen have been employed to study cell behaviors such as vascular EC migration, proliferation, differentiation, and phenotypic expression [51-55]. We previously demonstrated using arrayed ECM microenvironments that human induced pluripotent stem cell (iPSC)-derived ECs cultured on multi-component ECMs containing purified collagen IV had a positive impact on cell viability in hypoxia, as well as in supporting nitric oxide production and phenotypic marker expression of CD31 [56]. Scaffolds derived from purified collagen I enhanced the survival of ECs derived from induced pluripotent stem cells for treatment of peripheral arterial disease in a murine model [57]. In addition, some studies suggest that collagen I is involved in the biological and electrophysiological function of the myocardium [58-60], and therefore it has been used extensively in cardiovascular regeneration applications [58,61]. Schenke-Layland et al. showed that collagen type IV coatings promote induced pluripotent stem cell differentiation into cardiovascular and hematopoietic lineages [62]. These examples highlight the utility of purified collagen as a biomaterial for modulating cell function and survival. To better reproduce the characteristic of cardiovascular tissue ECM, several researchers have used collagen in combination with a fibrous protein, fibrin. Fibrin mitigates the risk of immunological incompatibility, and its biodegradable along with tunable physical properties makes it a suitable ECM protein for tissue engineering and regenerative medicine. Fibrin possesses both elastic and viscous properties, and incorporation with fibrin has been shown to enhance physical property and increased tissue compaction, a morphogenetic process improving structural tightness [63].

Elastin: Another essential ECM component that provides elasticity to the cardiovascular tissue is elastin, which is involved in cellular functions such as cellular attachment, proliferation, differentiation, and migration [64]. Wang et al. demonstrated that collagen-elastin hydrogels support the proliferation and protein expression of valve interstitial cells and valve ECs providing enhanced physical strength and elasticity [65]. Edalat et al. developed a hybrid hydrogel consisting of components Matrigel ${ }^{\mathrm{TM}}$, type 1 collagen, and growth factors that showed enhanced cardiomyocyte differentiation.

Decellularized extracellular matrix (dECM): Decellularization is the process of removing cells and cellular debris from a tissue or organ and isolating the extracellular matrix (ECM). The decellularized ECM contains proteins, proteoglycans, and glycosaminoglycans responsible for cell adhesion, cell remodeling, and mechanotransduction. Importantly, $\mathrm{dECMs}$ do not contain many immunogenic components that are found in the native tissue, making them attractive for cardiovascular tissue engineering and regenerative medicine applications. In addition, tissue-specific $\mathrm{dECMs}$ also retain the biochemical and structural properties necessary for tissue function [66,67]. The general guidelines for acceptable amounts of residual DNA after decellularization are $<50 \mathrm{ng}$ dsDNA per mg dry weight and $<200$ base pair DNA fragment length. An optimized decellularization process effi- 
ciently removes the cellular components of ECM but also preserves the microstructural, biomechanical, and biochemical properties of ECM. A combination of different mechanical, chemical, and enzymatic decellularization methods is commonly used to obtain suitable dECM for intended application.

Several studies have conducted optimization of decellularization methods using physical, chemical, and biological treatments [68-70]. McFetridge et al. developed a two-step decellularization process of porcine carotid artery using various solvents and trypsin to extract the lipid and cellular proteins, respectively. They and demonstrated that the composition of the solvents used for lipid extraction significantly affected the AECM modulus, concluding that an ethanol-butanol-ethanol three-step extraction preserves the mechanical properties of $\mathrm{dECM}$, comparable to that of control tissue [71]. Apart from decellularization process, the tissue origin, age, and species were also found to be important in specific applications, due to the role of these factors in the microstructure, mechanical properties, and composition of ECM. Sellaro et al. showed that sinusoidal ECs maintained their phenotype in culture longer when seeded on liver AECM compared to the ECM derived from bladder or small intestine [72]. Although dECMs derived from the corresponding tissues of non-human sources might not be ideal for clinical applications, they still hold promise to be translated into the clinic, particularly for cardiovascular regeneration. This is due to their similar microstructure, mechanical properties and composition, and greater abundance, compared to that of human AECM. The overall microstructure of ECM remains unchanged by aging. However, the composition and structural organization of ECM components, particularly proteins, undergo substantial changes over time, which further modulates the mechanics of ECM as well as cellular responses [73].

$\mathrm{dECM}$ exhibits great potential for the regeneration of engineered cardiac and vascular tissues. $\mathrm{dECM}$ has been widely used owing to the preservation of natural bioactive molecules that foster homeostasis and facilitate the tissue regeneration process $[69,74-77]$. One of the seminal papers in AECM translation is the work by Ott et al., who developed a bioartificial tissue engineered myocardium with a preserved ECM composition using coronary perfusion-based whole organ decellularization of rat hearts, followed by recellularization with neonatal cardiac cells and rat aortic ECs [77]. The constructs exhibited contractile function. Cardiac tissue-derived ECM has also been shown to promote in vitro differentiation and maturation of cardiomyocytes derived from human embryonic stem cells or human induced pluripotent stem cells $[78,79]$. Bosara et al. developed hydrogels using decellularized human myocardium-derived ECM with gelatin methacryloyl (GelMA) or GelMA-methacrylated hyaluronic acid (MeHA). The hydrogels supported the growth of human induced pluripotent stem cells derived cardiomyocytes (iCMs) and human cardiac fibroblasts (hCFs) [79]. Similar approaches have also been taken to decellularize blood vessels [80], and the decellularized vessels have been shown to be safe for in vivo implantation [81].

Mesenchymal stem cells (MSCs) have been widely reported to promote in vitro and in vivo angiogenesis [82]. Bone marrow-derived MSCs have shown success in clinical applications for angiogenesis in cardiovascular diseases like critical limb ischemia [83]. It has been shown that both adult bone marrow-derived and adipose-derived MSCs can stimulate angiogenesis [84]. MSCs derived from prenatal and adult tissues have also shown the potential for immunomodulatory function [85] and hematopoietic support [86]. MSC-derived ECMs have also been shown to have angiogenic potential [87-89]. MSCs and ECs in co-culture deposited decellularized ECM deposited by the co-culture of MSCs and ECs stimulated an angiogenic response by facilitating cross talk through paracrine and juxtacrine cellular interactions between MSCs and ECs [89]. Yael et al. fabricated hybrid ECM-based hydrogels using decellularized porcine cardiac extracellular matrix (pcECM) and demonstrated that these hydrogels are naturally remodeled by MSCs, supporting cellular viability, morphology, and organization. The hydrogels exhibited no in vitro or in vivo immunogenicity. Further, in a rat model of chronic myocardial infarction (MI), the 
pcECM-based hydrogels enabled improvement in cardiac function 12 weeks post MI [90]. The effects of ECM-based biomaterials are summarized in Table 1.

Table 1. Effect of ECM-based biomaterials on cardiovascular lineages.

\begin{tabular}{|c|c|c|c|c|}
\hline ECM & $\begin{array}{l}\text { ECM-Based } \\
\text { Biomaterials }\end{array}$ & Model & $\begin{array}{l}\text { Cardiovascular Tissue } \\
\text { Engineering Advantages }\end{array}$ & Ref. \\
\hline Collagen & COL I & Murine & $\begin{array}{l}\text { Cardiomyocyte differentiation, } \\
\text { maturation and contractile function }\end{array}$ & [90] \\
\hline Collagen & $\begin{array}{l}\text { ESC and } \\
\text { iPSC/COL IV }\end{array}$ & In vitro & $\begin{array}{l}\text { Differentiation of induced pluripotent } \\
\text { stem cells (iPSs) into cardiomyocytes of } \\
\text { contractile function. }\end{array}$ & [91] \\
\hline $\begin{array}{l}\text { Collagen and } \\
\text { Fibrin }\end{array}$ & COL $1 /$ Fibrin & In vitro & $\begin{array}{l}\text { Improved physical property, cardiac } \\
\text { tissue compaction }\end{array}$ & {$[63]$} \\
\hline $\begin{array}{l}\text { Collagen and } \\
\text { Elastin }\end{array}$ & COL 1/Elastin & In vitro & $\begin{array}{c}\text { Enhanced elasticity, maturation of valve } \\
\text { interstitial cells and valve ECs. }\end{array}$ & {$[65]$} \\
\hline Fibrin & Fibrin & In vitro & $\begin{array}{l}\text { Cardiomyocyte proliferation and } \\
\text { cardiac regeneration }\end{array}$ & [92] \\
\hline Collagen & 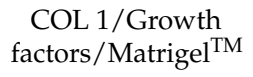 & In vitro & $\begin{array}{l}\text { Cardiomyocyte differentiation } \\
\text { and maturation }\end{array}$ & {$[93]$} \\
\hline $\mathrm{HA}$ & $\mathrm{HA}$ & In vitro & $\begin{array}{l}\text { Attenuates cardiac fibrosis and promote } \\
\text { cardiac muscle tissue regeneration }\end{array}$ & {$[94,95]$} \\
\hline
\end{tabular}

Abbreviations: ESC (embryonic stem cell); iPSC (induced pluripotent stem cell); COL 1 (collagen I); COL4 (collagen IV); EC (endothelial cell); HA (hyaluronic acid).

Table 2.

The biological response of cardiovascular tissue to dECM scaffolds is summarized in

Table 2. Decellularized ECM-based biomaterials and cardiovascular response.

\begin{tabular}{|c|c|c|c|c|}
\hline Tissue/Organ & Decellularization Method & Model & Vascular Response & Ref. \\
\hline $\begin{array}{c}\text { Adult } \\
\text { Porcine Heart }\end{array}$ & $\begin{array}{l}\text { Pulsatile retrograde aortic } \\
\text { perfusion }\end{array}$ & Porcine & $\begin{array}{l}\text { Chicken cardiomyocytes were cultured. ECM } \\
\text { retained collagen, elastin, glycosaminoglycans, and } \\
\text { mechanical integrity. }\end{array}$ & [96] \\
\hline $\begin{array}{c}\text { Porcine } \\
\text { Whole Heart }\end{array}$ & $\begin{array}{l}\text { Perfusion of Trypsin/EDTA } \\
\text { and Triton-X100/deoxycholic } \\
\text { acid (DCA) }\end{array}$ & Porcine & ECM retained elastin, collagen, and proteoglycan & [97] \\
\hline Rat Heart Adult & $\begin{array}{l}\text { Three decellularization } \\
\text { solutions were used: } \\
\text { (1) SDS/TritonX100- v/s (2) } \\
\text { Trypsin plus Triton/DCA v/s } \\
\text { (3) SDS/DCA/saponin }\end{array}$ & In vitro & $\begin{array}{c}\text { C2C12 myoblasts were seeded in vitro. ECM retained } \\
\text { laminin in all groups, elastin in groups } 1 \text { and } 2, \\
\text { collagen in groups } 1 \text { and } 3 .\end{array}$ & [98] \\
\hline Porcine Aortic Valves & Triton X-100 & In vitro & $\begin{array}{c}\text { ECs were seeded. EC mediated ECM deposition } \\
\text { was observed. }\end{array}$ & [99] \\
\hline $\begin{array}{l}\text { Human } \\
\text { Umbilical } \\
\text { Artery }\end{array}$ & SDS treatment & In vitro/In vivo & $\begin{array}{c}\text { In vitro EC cell seeding and implantation in rats. EC } \\
\text { culture growth was sustained for } 8 \text { weeks, } \\
\text { ECM preserved. }\end{array}$ & [100] \\
\hline $\begin{array}{l}\text { Tissue } \\
\text { Engineered Porcine } \\
\text { Vessels }\end{array}$ & SDS & In vitro/Porcine & $\begin{array}{l}\text { Pre-seeding of EC progenitor cells and implantation } \\
\text { in porcine carotid artery. No clotting observed. No } \\
\text { signs of intimal hyperplasia. }\end{array}$ & [101] \\
\hline $\begin{array}{l}\text { Bioartificial Tissue } \\
\text { Engineered Heart }\end{array}$ & $\begin{array}{l}\text { Coronary perfusion-based } \\
\text { whole organ decellularization }\end{array}$ & In vitro/rat model & $\begin{array}{l}\text { Recellularization with neonatal cardiac cells and rat } \\
\text { aortic ECs. Constructs exhibited contractile function } \\
\text { and EC culture growth. }\end{array}$ & {$[77,78]$} \\
\hline $\begin{array}{l}\text { Neonatal Mouse } \\
\text { Heart }\end{array}$ & $\begin{array}{l}\text { Liquid nitrogen, erythrocyte } \\
\text { lysis, and DNA/RNA removal }\end{array}$ & $\begin{array}{l}\text { In vivo model of } \\
\text { acute MI }\end{array}$ & $\begin{array}{l}\text { nmECM showed improved heart function compared } \\
\text { to adult heart derived ECM, cardiac repair after MI }\end{array}$ & [79] \\
\hline $\begin{array}{c}\text { Cardiac } \\
\text { Porcine Hearts }\end{array}$ & to & In vitro & $\begin{array}{l}\text { cdECM promotes human cardiac fibroblast culture } \\
\text { and human iPSC-derived cardiomyocytes. } \\
\text { Decellularized porcine myocardial extracellular }\end{array}$ & [102] \\
\hline $\begin{array}{l}\text { Porcine Cardiac } \\
\text { Tissue }\end{array}$ & SDS & In vivo & $\begin{array}{l}\text { matrix }(\mathrm{dECM}) \text {-reduced graphene oxide hydrogel } \\
\text { promoted increased expression of genes that } \\
\text { regulated contractile function. }\end{array}$ & [103] \\
\hline Porcine Heart & SDS & In vitro & $\begin{array}{l}\text { Enhanced maturation of cardiomyocytes (isolated } \\
\text { from neonatal rats) in hdECM }\end{array}$ & [104] \\
\hline $\begin{array}{l}\text { Rat Heart } \\
\text { Tissue }\end{array}$ & Ionic and non-ionic detergents & In vivo & $\begin{array}{l}\text { (AdMSCs) promoted increased } \\
\text { cardiomyocyte-specific gene expression for } \\
2-4 \text { weeks. }\end{array}$ & [105] \\
\hline
\end{tabular}

Abbreviations: SDS (sodium dodecyl sulfate); EC (endothelial cells); ECM (extracellular matrix); DCA (deoxycholic acid); MI (myocardial Infarction); nmECM (ECM derived from neonatal mouse hearts); $\mathrm{cdECM}$ (cardiac decellularized ECM); iPSC (induced pluripotent stem cell); dECM (decellularized ECM); hd ECM (heart tissue-derived ECM); (AdMSCs) adipose tissue-derived mesenchymal stem cells. 
Cell Culture-Derived ECM: Decellularized ECMs derived from tissues have been used as biomaterial scaffolds in tissue engineering. They have the advantage of maintaining the structure of their respective tissues and organs. However, concerns of limited autologous tissue/organ availability, immune responses, and the risk of pathogens from allogenic and xenogeneic tissues have led to the rise of cell culture-derived ECM scaffolds [106]. Cell culture-derived ECM can be developed into 3D scaffolds or reconstituted with natural or artificial polymers for tissue engineering applications [107-109]. Cultured cells have advantages over tissues such as the following. Cultured cells can be maintained in pathogen free conditions. Cell-derived scaffolds can provide the accurate geometry and porosity and optimal cell penetration that is difficult to achieve in tissue derived scaffold. In vitro cultured cell types can be used to combine their respective ECMs. Furthermore, autologous cells can generate their own ECM that obviates immune responses. Lu and colleagues developed ECM scaffolds derived from MSCs, chondrocytes, and fibroblasts by culturing cells in a poly(lactic-co-glycolic acid) (PLGA) template [110]. The ECM scaffolds promoted cell proliferation, cell adhesion and ECM production. Fibroblasts cultured in the fibroblast-derived ECM scaffolds proliferated and produced ECM to fill the pores of the scaffold. In 2 weeks of culture, a multi-layered tissue was produced with homogenously confluent fibroblasts [110].

\section{ECM Regulation of Vascular Function and Cell Fate}

Blood vessels carry out a critical role in blood circulation and have layers of structures of varied structure and function. They have a complex structure of with layers of thick and elastic walls (tunica intima, tunica media, tunica adventitia). The tunica media consist of SMCs that provide contractility, whereas the tunica adventitia provides connective tissue support [111]. The tunica intima, an essential part of blood vessel, consists of a monolayer of ECs that constitute the interior surface and basal lamina that encloses it. The basal lamina contains type IV, XV, and XVIII collagens; laminin; fibronectin; heparan sulfate proteoglycan; and other macromolecules [112]. ECs attach to the basal lamina and degrade it when initiating angiogenesis. Laminin is the most abundant protein in the basal lamina and serves as the foundation for the protein network and supports migration, proliferation, and differentiation of ECs [113]. Nguyen et al. demonstrated that laminin supports differentiation of human embryonic stem cells into functional endothelial progenitor cells [114]. Stamati et al. showed that laminin facilitates the 3D in vitro vascular network formation in collagen hydrogels by promoting the uptake of vascular endothelial growth factor by ECs [115].

The endothelial basement membrane is comprised of a milieu of different ECMs such as laminin, type IV collagen, fibronectin and heparan sulfate proteoglycans [116]. It is well recognized that the endothelial basement membrane provides signaling cues for physiological endothelial behavior and function [117]. These biochemical and physical cues modulate endothelial cell adhesion, migration, proliferation, differentiation, and the cellular signaling network. The biochemical and physical cues also participate in the angiogenesis process [117]. During angiogenesis, the basement membrane is degraded by matrix metalloproteinases (MMPs) limiting the presence of type IV collagen. The ECM, with a high laminin content, stretches out resulting in its increased compliance that promotes migration and proliferation of endothelial cells [117].

Multi-component ECM scaffolds have shown potential to promote iPSC-EC viability, endothelial phenotype, and nitric oxide production under hypoxia [118]. Using an arrayed ECM microenvironment platform, we previously showed that multi-component ECMs generally improved endothelial differentiation of human induced pluripotent stem cells, compared to single-component ECMs. Combinatorial ECMs such as collagen IV + gelatin + heparan sulfate + laminin and collagen IV + fibronectin + gelatin + heparan sulfate + laminin were shown to significantly improve cell survival, nitric oxide production, and CD31 phenotypic expression, compared to single-component ECMs. Among them, the collagen IV-containing multi-component ECMs supported the endothelial differenti- 
ation, based on multifactorial bioinformatic analysis [118]. This approach reveals ECM interactions and cellular behavior in response to complex environmental cues that cannot be exhibited by conventional cell culture platforms especially under conditions such as hypoxia and nutrient and growth factor deficiency.

Biodegradable ECM-based biomaterials related to the basal lamina including collagen and fibronectin have been utilized for studying EC function. Integrin-dependent binding to RGD cell adhesive regions on collagen nanofibrils or fibronectin reinforces endothelial sprouting $[119,120]$. Daum et al. showed that fibronectin coating on synthetic vascular grafts supports endothelium formation [121]. RGD-modified HA hydrogels seeded with ECs improved cell proliferation, migration, and capillary-like network formation, while promoting the formation of functional vasculature after in vivo implantation [122]. In another example, endothelial progenitor cells encapsulated in blood vessel derived dECM exhibited higher proliferation capability and enhanced vascular network formation, compared to collagen hydrogel [123]. These studies illustrate the ability of ECM-based biomaterials to modulate endothelial behavior, including their organization, proliferation, and sprouting. Table 3 illustrates different ECM-based biomaterials and their impact on endothelial growth, differentiation, and function.

Table 3. ECM-mediated endothelial differentiation and function.

\begin{tabular}{|c|c|c|c|}
\hline ECM Component & Model & Endothelial Cell Response & Ref. \\
\hline Laminin & In vitro & $\begin{array}{l}\text { Differentiation of embryonic stem cells into } \\
\text { functional endothelial progenitor cells. }\end{array}$ & [114] \\
\hline Laminin & In vitro & $\begin{array}{l}\text { Laminin facilitates in vitro 3D vascular network } \\
\text { formation by promoting uptake of VEGF by ECs. }\end{array}$ & [115] \\
\hline COL IV- multi-component ECM & In vitro & $\begin{array}{l}\text { Improved endothelial differentiation of human } \\
\text { induced pluripotent stem cells. }\end{array}$ & [118] \\
\hline Fibronectin & In vitro & $\begin{array}{l}\text { EC growth and proliferation was supported by } \\
\text { fibronectin coating on vascular grafts. }\end{array}$ & [121] \\
\hline RGD-modified HA & In vivo & $\begin{array}{c}\text { EC migration and proliferation, formation of } \\
\text { functional vasculature }\end{array}$ & [122] \\
\hline dECM & In vitro & $\begin{array}{c}\text { endothelial progenitor cells encapsulated in blood } \\
\text { vessel-derived dECM exhibited higher } \\
\text { proliferation capability and enhanced vascular } \\
\text { network formation. }\end{array}$ & [123] \\
\hline $\mathrm{dECM}$ & In vitro & $\begin{array}{l}\text { In vitro EC cell seeding and implantation in rats. } \\
\text { EC culture growth was sustained for } 8 \text { weeks, } \\
\text { ECM preserved. }\end{array}$ & [100] \\
\hline $\mathrm{dECM}$ & In vivo & $\begin{array}{c}\text { Hybrid ECM promoted proliferation and } \\
\text { migration of HUVECs, significantly inhibited } \\
\text { immune response and calcification, exhibited } \\
\text { stability and biocompatibility compared to } \\
\text { non-hybrid leaflet. }\end{array}$ & [124] \\
\hline Heparin & In vitro & $\begin{array}{c}\text { Surfaces covalently immobilized with heparin } \\
\text { promoted endothelial cell growth and } \\
\text { inhibited SMCs. }\end{array}$ & [125] \\
\hline $\mathrm{Fb} / \mathrm{COL} / \mathrm{LA} / \mathrm{FN}$ & In vitro & $\begin{array}{l}\text { High EC cell densities were achieved in } 7 \text { days } \\
\text { of culture }\end{array}$ & [126] \\
\hline Fibrin Fragment E (FbnE) & In vitro & $\begin{array}{l}\text { Increased adhesion and endothelial differentiation. } \\
\text { Continuous EC monolayer was observed on } \\
\text { collagen coated membrane. ECs exhibited }\end{array}$ & [127] \\
\hline COL Coated PCL Membrane & In vitro & $\begin{array}{l}\text { filopodia protruding from lamellipodia in the } \\
\text { junctional areas on the } \\
\text { collagen-coated membranes. }\end{array}$ & [128] \\
\hline $\begin{array}{l}\text { Matrigel Matrix Comprising of } \\
\text { LA, COL IV, Heparen Sulfate } \\
\text { Proteoglycans }\end{array}$ & Ischemic mouse model & $\begin{array}{l}\text { Improved neovasculature formation, promote cell } \\
\text { growth, proliferation and differentiation of ECs. }\end{array}$ & [129] \\
\hline $\begin{array}{l}\text { Cardiogel Composed of LA, FN } \\
\text { and Interstitial COL I and IV }\end{array}$ & In vivo & $\begin{array}{l}\text { ECM components promote growth of ECs and } \\
\text { CMs, spontaneous contractile activity and } \\
\text { phenotypic morphological differentiation. }\end{array}$ & [130] \\
\hline
\end{tabular}

Abbreviations: VEGF (vascular endothelial growth factor); EC (endothelial cells); ECM (extracellular matrix); DCA (deoxycholic acid); MI (myocardial Infarction); nmECM (ECM derived from neonatal mouse hearts); cdECM (cardiac decellularized ECM); iPSC (induced pluripotent stem cell); dECM (decellularized ECM); hd ECM (heart tissue-derived ECM); (AdMSCs) adipose tissue-derived mesenchymal stem cells; HA (hyaluronic acid); Fb (fibrin); LA (laminin); FN (fibronectin); COL (collagen); PCL (polycaprolactone). 


\section{Considerations of Hydrogel Assembly, Biofabrication, and Spatial Patterning}

3D Hydrogel Assembly: ECM hydrogels have been one of the major advancements in the engineering of ECM-based biomaterials. Hydrogels are injectable and compatible with several fabrication technologies including 3D printing, micropatterning, and electrospinning, thereby expanding the clinical applications of ECM-based biomaterials. Hydrogels are hydrated polymers or materials with $\geq 30 \%(v / w)$ water content that use crosslinks between their constituents to maintain their structural integrity [131]. Some ECMs can self-assemble to form hydrogels such as collagen, elastin, hyaluronic acid (HA), and alginate [132]. Other hydrogels are commonly made of synthetic [133] polymers such as poly (vinyl alcohol) (PVA), poly (acrylic acid) (PAA), polyethylene oxide (PEO), and poly(propylene fumarateco-ethylene glycol) [P(PF-co-EG)]. Synthetic hydrogels can also be formed from proteins with biomimetic cell adhesive ligands such as RGD (from fibronectin) and YIGSR (from laminin) [134]. Furthermore, polymer functionalized multi-component hydrogel networks of ECM molecules have been designed to better mimic the physical properties or biochemical complexity of native tissues [135]. Tri-component networks composed of collagen, methacrylate-modified chondroitin sulfate, and HA [135]; methacrylated HA within a fibrin hydrogel [136]; and interpenetrating polymer networks of photocrosslinked HA and collagen [137] are all examples of such multi-component hydrogels. The main advantage of multi-component hydrogels over conventional single-component ECM hydrogel is that multi-component ones may better mimic the biochemical and/or mechanical complexity of ECMs in native tissue. However, a limitation is that multi-component hydrogels may be more difficult or time consuming to fabricate consistently, compared to single-component ECM hydrogels.

Decellularized ECM can also be used to produce hydrogels through enzymatic solubilization of the ECM, followed by neutralization to physiological $\mathrm{pH}$ and temperature $[138,139]$. ECM hydrogels derived from decellularized tissues can recapitulate aspects of physiological tissues or stem cell niches. Accordingly, they are an attractive substrate for 3D organoid culture to promote the proliferation and differentiation of stem cells $[130,140]$ as well as tissue morphogenesis [141]. The biochemical, topological, and viscoelastic properties of ECM hydrogels [142] depend on the tissue from which they are derived along with the decellularization procedure. ECM hydrogels have been proposed to have the potential to promote endogenous repair of the myocardium [143] as they mitigate the expression of pro-inflammatory and pro-apoptotic genes and promote blood vessel formation and recruitment and differentiation of stem and progenitor cells in the heart.

Bioprinting: In order for hydrogels to reproduce the anatomy and multicellular arrangement of human cardiovascular tissue $[144,145]$, biofabrication strategies have been shown to be useful. 3D bioprinting techniques such as inkjet, microextrusion-based, and laser-assisted bioprinting regulate effective control of biomaterial disposition. With recent advancements, some bioprinting approaches also incorporate topographical and biochemical cues [141]. Various 3D bioprinting techniques have respective strengths and limitations (Table 4). Biomaterial inks used in bioprinting should support cellular viability, proliferation, maturation, and differentiation in the engineered cardiovascular tissue construct [146]. Moreover, the inks should also possess mechanical properties and printability such as viscoelasticity, shear thinning property, and tissue maturation efficiency post bioprinting [147] for structural mimicry for cardiovascular tissue-specific anatomy. Zhang et al. developed a co-axial 3D bioprinting method having the bio-ink as GelMA/alginate blended hydrogel seeded with ECs at the inner needle and calcium chloride at the outer needle for ionic crosslinking, followed by seeding cardiomyocytes onto the engineered scaffold to produce endothelialized myocardium [147]. In two weeks of culture, a layer of endothelium was formed surrounding the microfibers. These examples demonstrate the advancement of increasingly complex geometries using bioprinting strategies.

A strength of $3 \mathrm{D}$ bioprinting is that it allows the rapid fabrication of functionalized tissue with physiologically relevant architecture and microenvironmental cues. Additionally, 3D bioprinting is capable of handling a large number of cells while also being scalable. 
However, it is difficult to replicate native human cardiovascular tissues/organs without a biomaterial or "bio-ink" that enables precise fabrication and promotes cellular behavior. ECM-based biomaterials are promising bio-inks because they facilitate the engineering of functional cardiovascular tissue by supporting biological activity, tissue resilience, and structural mimicry. Decellularized ECM bio-ink contains biochemical cues from the original native ECM microenvironment required for cellular proliferation and growth with the appropriate proportions of ECM proteins. Cell-specific bio-inks could be tailored for bioprinting of specific cell types to stimulate physiological mechanisms in cellular models. The convergence of ECM with 3D printing technology holds great potential for printing complex bio-scaffolds especially biomimetic 3D structures. With these advancements, a highly organized and functional cardiovascular tissue (i.e., myocardium, heart valve, and vasculature) can be engineered that is structurally and functionally more similar to native cardiovascular tissue that is suitable for transplantation, drug development, and disease modeling.

Each of the biofabrication strategies to generate functional tissue constructs depend on bio-inks that encapsulate cells, and their requirements depend on the printing modality. For example, inkjet bioprinting requires relatively lower viscosities to prevent clogging and low conductivity the prevent cellular heat damage. Extrusion-based biofabrication processes can accommodate high viscosities but require shear thinning materials to prevent cellular mechanical damage [148,149]. In extrusion-based fabrication processes, the bio-ink is extruded continuously through a deposition nozzle. Therefore, low viscosity is desirable during extrusion to avoid high shear stress and potential clogging. Upon deposition, a high viscosity rate is needed to maintain shape and high print fidelity to preserve high printing precision such as thermo-responsive gelation of gelatin that retains its shape of printed structure [150]. However, gelatin is not used alone in biofabrication as its reversible sol-gel transition can affect printing temperature and viscosity [151]. Similarly, PEG solution has low viscosity and is too soft to keep its shape post printing [152,153]. Bio-inks containing cells must also remain viable during the fabrication process [154]. Hydrogels such as agarose maintain their structural integrity through high polymer concentration. However, the resulting high viscosity can affect cell viability; hence, agarose hydrogels are used as sacrificial structures [148]. High structural integrity is an indicator of success in applications such as vascular grafts [148,155].

Biomaterials have physical, chemical, and biological properties that influence the biofabrication process. These include viscosity, shear thinning, viscoelasticity, gelatin kinetics, biocompatibility, biodegradation, and hydration degree [156]. The rate of gelatin affects the print fidelity by determining the speed of hydrogel crosslinking after printing [148]. Advanced biomaterials such as hydrogels use multiple approaches to improve printability and cytocompatibility. For example, biomaterials such as supramolecular hydrogels, interpenetrating network and nanocomposites are designed with shear thinning characteristics and have lower viscosities at high shear rates of extrusion. Post extrusion, an increase in viscosity results in high print fidelity and cell viability. Biodegradation of hydrogels can occur enzymatically (i.e., collagen, gelatin), hydrolytically (i.e., polyester), or through ion exchange (i.e., alginate) [155]. The degradation kinetics of hydrogels modulate ECM production and remodeling.

ECM-based hydrogels can be modified to improve their strength, shape integrity or resistance to rapid degradation. Hydrogels made from matrix molecules (i.e., a gel formed from myocardia matrix) have been reported to have low stiffnesses of 5-10 $\mathrm{Pa}$ at $1 \mathrm{~Hz}$ [157]. Low mechanical integrity and modulus can negatively affect cell adhesion, migration, and signal transport. Christman and collaborators showed that the addition of PEG to the either NHS or PEG diacrylate can increase the storage modulus of the gel (5-30 Pa), compared to ECM gel (5 Pa) [157]. The incorporation of PEG allowed for tunable degradation, compared to ECM gel that exhibited degradation times 2-3 times faster than the hybrid gel. Cell studies reveal that cellular adhesion, migration, and encapsulation of myocardial-PEG-NHS or acrylate hydrogels was efficient compared to ECM gels that 
showed very low cell encapsulation efficiency [157]. Mintz and collaborators reported that the storage modulus of polycaprolactone (PCL) porous scaffolds injected with HA hydrogel [158] was higher than that of hydrogel alone and lower than the PCL scaffold alone. However, the hybrid biomaterial did have a noticeably different Young's modulus compared to the PCL scaffold, demonstrating that hybrid scaffolds can provide high stiffness characteristics in compression and tension (PCL component), while concurrently exhibiting viscoelastic properties of hydrogels (HA).

Table 4. Advantages and limitations of bioprinting techniques.

\begin{tabular}{|c|c|c|c|}
\hline 3D Bioprinting Technique & Advantages & Limitations & Ref. \\
\hline Inkjet Bioprinting & $\begin{array}{c}\text { Uses thermal, electromagnetic or piezoelectric } \\
\text { technology to deposit droplets of } \\
\text { "ink" (materials) } \\
\text { Rapid printing speeds and high resolution. } \\
\text { Capable of printing low-viscosity biomaterials. } \\
\text { Availability and ease of replacement of } \\
\text { bio-inks. High-cell viability and relatively } \\
\text { low cost }\end{array}$ & $\begin{array}{l}\text { Low material viscosity }(<10 \mathrm{~Pa} \cdot \mathrm{s}) \text { and low } \\
\text { droplet directionality. Lack of precision with } \\
\text { respect to droplet size. Requirement for low } \\
\text { viscosity bio-ink. Nozzle clogging and cellular } \\
\text { distortion due to high-cell density. Low } \\
\text { mechanical strength. Inability to provide } \\
\text { continuous stream of material. }\end{array}$ & [159] \\
\hline Micro-Extrusion & $\begin{array}{l}\text { Ability to print biomaterials with high cell } \\
\text { densities (higher than } 1 \times 10^{6} \text { cells } \mathrm{mL}^{-1} \text { ) } \\
\text { comparable to physiological cell densities. Can } \\
\text { produce continuous stream of material. Can } \\
\text { successfully print high viscosity bio-inks such } \\
\text { as polymers, clay-based substrates. }\end{array}$ & $\begin{array}{l}\text { Low printing resolution }(>100 \mu \mathrm{m}) \text { and slow } \\
\text { printing speeds. Loss of cellular viability and } \\
\text { distortion of cellular structure due to the } \\
\text { pressure to expel the bio-ink. }\end{array}$ & [160] \\
\hline $\begin{array}{l}\text { Laser-Assisted } \\
\text { Bioprinting: SLA and LIFT }\end{array}$ & $\begin{array}{l}\text { Rapid printing speeds and ability to print } \\
\text { biomaterials with wide range of viscosities } \\
\text { (1-300 } \mathrm{mPa} / \mathrm{s}) \text {. High degree of precision and } \\
\text { resolution }(1 \text { cell/droplet). Can successfully } \\
\text { print high density of cells } 10^{8} \mathrm{~mL}^{-1}\end{array}$ & $\begin{array}{c}\text { Time consuming: need to prepare } \\
\text { reservoirs/ribbons. Lower cellular viability } \\
\text { compared to other methods. Loss of cells due } \\
\text { to thermal damage. SLA requires intense UV } \\
\text { radiation for crosslinking process. Requires } \\
\text { large amount of material. High cost. Long post } \\
\text { processing time and fewer materials } \\
\text { compatible with SLA. }\end{array}$ & {$[161,162]$} \\
\hline
\end{tabular}

Abbreviations: LIFT (laser-induced forward transfer); SLA (stereolithography SLA).

Spatial Patterning: Each organ and tissue has a distinct ECM composition and ultrastructure that modulates cell behavior [163]. This can be recreated by micropatterning of ECM components onto synthetic materials [164]. Photolithography or light-based patterning can be used for differential ECM protein deposition onto a substrate. It has the potential to achieve a resolution of 500-5000 $\mu \mathrm{m}$ [165], but the high cost of photolithographic equipment and clean room maintenance [166] are a few limitations of the technique. On the other hand, elastomeric stamping techniques are procedurally simple and inexpensive [167], have improved control mechanisms, can incorporate microchannels and microfluidics, and enable patterning of gradients of ECM components. Additionally, the electrospinning technique employs a current to induce the formation of nano- to micro-scale fibers that can be arranged in parallel alignment $[168,169]$. Furthermore, nanofiber lithography can be used to fabricate fibrous nanopatterned scaffolds with a resolution of 250-1000 nm [170] and regulates cell adhesion through modulation of integrin expression. In another approach, we developed a facile shear-based approach for the fabrication of spatially nanopatterned collagen scaffolds that support the parallel organization of vascular ECs and SMCs [171].

Cellular signaling pathways are regulated by the composition, topography, and mechanical properties of micropatterned ECM substrates. For example, the shape and phenotype of macrophages can be modulated by the elasticity and rigidity of micro-patterned substrates with fibronectin without exogenous cytokines [172]. Substrate elasticity can modulate actin polymerization and activation of stretch sensitive ion channels that can mediate changes in macrophage gene expression and cytokine secretion. Angiogenesis has similarly been shown to be modulated by micropatterning as strong mechanical forces [173,174], as the convex part of micropatterned vessel walls promote preferential formation of blood vessels. We previously demonstrated that parallel-aligned micropatterned channels as well as nanopatterned collagen scaffolds promote the organization and migration of ECs [175]. 
Even when laminar flow was applied to EC-seeded parallel-aligned nanofibrillar collagen scaffolds orthogonal to the direction of collagen patterning, the cells preferentially remained organized along the direction of spatial patterning. Mechanical forces can modulate very important cellular [175-178] and biological functions such as differentiation [179], apoptosis [180], gene expression [181], and RNA processing [182], emphasizing the critical role of ECM structure, topography, and mechanics for tissue remodeling. Even though recent advancements in the imaging and data analysis techniques have helped reveal the remarkable ECM architecture, one of the challenges in the exact recreation of the ECM structure by spatial patterning is the detailed mapping of the native ECM topography.

\section{Translational Applications of ECM-Based Biomaterials}

\subsection{Engineered Vascular Grafts}

Autologous blood vessels are the gold standard for bypass graft surgeries. However, their use is limited due to the lack of suitability vessels, especially in diseased patients, owing to low quality and high failure rates [183-186]. Alternatively, tissue-engineered small-diameter vascular grafts made from synthetic or natural polymers have not demonstrated adequate results, comparable to autologous grafts. Synthetic polymer grafts such as polyethylene terephthalate/Dacron and polytetrafluoroethylene/Teflon (ePTFE) have high failure rates comparable to small-diameter vascular grafts due to the lack of an endothelium, thrombosis, and intimal hyperplasia [187-190]. In contrast, scaffolds derived from purified ECMs such as collagen and fibrin are promising due to being biocompatible and promoting endothelialization [191-193].

Three different approaches have been employed for using ECM in vascular graft applications. These consist of cell-derived ECM, extracted 2D tissue, and cannular tissue. Cell-derived grafts are created from a monolayer or cannular-shaped culture of cells. After cells deposit ample ECM, the cells are removed, leaving behind decellularized ECM. The extracted 2D and cannular tissues produce grafts by decellularization and surface modification approaches. The grafts can be implanted in an acellular fashion or cultured with autologous ECs. For example, Niklason et al. utilized the cell-based ECM approach for small-diameter vascular grafts. The investigators seeded and cultured SMCs (bovine [194,195], porcine [194,196], canine [197], and human [197,198]) and human MSCs onto a polyglycolic acid (PGA) mesh scaffold for 8-10 weeks. During the culture period, the grafts demonstrated appropriate vessel wall thickness, suture retention strength, burst pressure, and collagen content [194,195]. These grafts have shown good long-term patency in vivo in canine and baboon models [197]. Further, these grafts showed promising patency results in clinical trials for hemodialysis access in patients with renal disease- $80 \%$ patency at 2 years [198]. Despite the positive patency results, the degradation components of PGA caused a phenotypic change of SMCs from contractile to synthetic, along with a lower expression of contractile proteins myosin, SMA, and calponin [101,194,195,199]. The phenotypic shift results in intimal hyperplasia and atherosclerosis [200-204]. Table 5 summarizes the different approaches to develop cell-derived extracellular matrix based vascular grafts.

Table 5. Cell-derived ECM strategies for engineering vascular grafts.

\begin{tabular}{|c|c|c|c|c|}
\hline Material & Treatment & Model & Vascular Graft Response & Ref. \\
\hline PGA Scaffold & SMC & Bovine & $\begin{array}{l}\text { Grafts exhibited goof vessel wall thickness, } \\
\text { burst pressure, and collagen content. }\end{array}$ & {$[194,195]$} \\
\hline PGA Scaffold & $\mathrm{SMC}$ & Canine & $\begin{array}{l}\text { Grafts exhibited good long-term patency for } \\
\qquad 8-10 \text { weeks. }\end{array}$ & [197] \\
\hline $\begin{array}{l}\text { PGA with Fibrinogen and } \\
\text { Thrombin }\end{array}$ & $\begin{array}{l}\text { SMC s and ECs derived } \\
\text { from hiPSC }\end{array}$ & Porcine & Grafts exhibited endothelial differentiation. & {$[194,196]$} \\
\hline PGA Scaffold & MSCs & In vitro & $\begin{array}{l}\text { Grafts exhibited superior mechanical } \\
\text { properties and cellular growth. }\end{array}$ & [198] \\
\hline Fibrin Gel & Human fibroblast (hDFs) & Baboon & Grafts exhibited higher patency rates of $>80 \%$. & [196] \\
\hline
\end{tabular}

Abbreviations: SMC (smooth muscle cells); EC (endothelial cells); hiPSC (human induced pluripotent stem cells); hDF (human dermal fibroblast); MSC (mesenchymal stem cells); PGA (polyglycolic acid). 
The most commonly used 2D scaffold for small-diameter vascular grafts is porcine small intestine submucosa (SIS). SIS has superior mechanical properties (burst pressure and compliance) analogous to native vessels, but low patency rates $[205,206]$. Decellularized SIS cultured with human vascular ECs showed higher proliferation rates and contractile morphology, compared to bare ePTFE and Dacron scaffolds [207]. SIS scaffolds treated with fibrinogen and thrombin showed EC culture and graft patency ex vivo [208]. The grafts were treated with heparin and pre-seeded with SMCs and implanted into sheep for 90 days. After the culture period, the grafts exhibited lumens with no sign of intimal hyperplasia or clotting [209]. The grafts with pre-seeded SMCs had a higher concentration of collagen content, indicating cellular maturation [209]. Table 6 summarizes the 2D tissues for vascular grafts.

Table 6. Two-dimensional scaffolds for vascular grafts.

\begin{tabular}{|c|c|c|c|c|}
\hline Material & Treatment & Model & Vascular Graft Response & Ref. \\
\hline SIS & EC culture & In vitro & $\begin{array}{l}\text { Grafts exhibited higher EC proliferation } \\
\text { and cobblestone morphology. }\end{array}$ & [207] \\
\hline SIS & $\begin{array}{l}\text { Pre-seeded with SMC and } \\
\text { fibrinogen/thrombin }\end{array}$ & Porcine & $\begin{array}{l}\text { Grafts exhibited endothelial cell } \\
\text { attachment and graft patency. }\end{array}$ & [208] \\
\hline SIS & Heparin & Sheep & $\begin{array}{l}\text { Grafts exhibited lumens with no sign of } \\
\text { clotting or intimal hyperplasia. }\end{array}$ & {$[194,196]$} \\
\hline Pericardium & MSCs & Bovine & $\begin{array}{c}\text { ECM and growth factors facilitated } \\
\text { differentiation into ECs. }\end{array}$ & [210] \\
\hline Porcine SIS Tubes & Heparin/VEGF & Sheep & $\begin{array}{l}\text { Grafts exhibited long term patency rates } \\
\text { for } 3 \text { months with a confluent endothelium } \\
\text { and no signs of thrombosis. }\end{array}$ & [211] \\
\hline
\end{tabular}

Abbreviations: SMC (smooth muscle cells); EC (endothelial cells); SIS (small intestine submucosa); MSC (mesenchymal stem cells); VEGF (vascular endothelial growth factor).

Decellularized porcine conduits require surface treatments to enhance hemocompatibility properties of the grafts. Ma and collaborators cultured decellularized porcine aortas with autologous ECs and confirmed long-term patency for 3 months [212]. Li and collaborators studied the in vitro efficacy of decellularized porcine carotid artery conduits cultured with hMSCs derived ECs and SMCs [213]. Immobilization of heparin on decellularized porcine carotid artery conduits exhibited anti-thrombogenic properties [214]. Table 7 summarizes cannular tissue studied for small diameter vascular grafts.

Table 7. Cannular tissues for vascular grafts.

\begin{tabular}{|c|c|c|c|c|}
\hline Material & Treatment & Model & Vascular Graft Response & Ref. \\
\hline Carotid Artery & Autologous EC & Porcine & Grafts exhibited patency rates of $>90 \%$ for 6 months. & [212] \\
\hline Carotid Artery & MSCs & Porcine & $\begin{array}{l}\text { ECM and growth factors cause differentiation of MSCs } \\
\text { into ECs. }\end{array}$ & [213] \\
\hline Carotid Artery & Heparin & Porcine & $\begin{array}{l}\text { Grafts exhibited lumens with no sign of } \\
\text { clotting/thrombus. }\end{array}$ & [214] \\
\hline Carotid Artery & MSCs & Porcine & $\begin{array}{l}\text { ECM and growth factors cause differentiation of MSCs } \\
\text { into SMCs. }\end{array}$ & [213] \\
\hline Porcine Aorta & Autologous ECs & Canine & Grafts exhibited long term patency rates for 3 months. & [210] \\
\hline Aorta & Heparin/VEGF & Canine & Grafts exhibited patency of $>90 \%$ post 2 years. & [214] \\
\hline $\begin{array}{l}\text { Porcine Pericardium } \\
\text { Scaffold }\end{array}$ & $\begin{array}{c}\text { Fibrin } \\
\text { mesh/Heparin/VEGF }\end{array}$ & Porcine & $\begin{array}{c}\text { Grafts exhibited potential to accelerate in situ } \\
\text { endothelialization. }\end{array}$ & [215] \\
\hline
\end{tabular}

Abbreviations: SMCs (smooth muscle cells); ECs (endothelial cells); MSCs (mesenchymal stem cells); VEGF (vascular endothelial growth factor).

\subsection{Cardiac Patches}

In order to overcome the limitations of traditional cellular therapy including the availability of oxygen and nutrients, the fabrication of thick 3D constructs of defined geometry and complexity and well-aligned cellular networks has been studied extensively [216]. Ventricular function lost in myocardial infarction can be regained by replacing the necrotic tissue with a tissue engineered "cardiac patch" [217,218]. Bioengineered functional cardiac tissue composed of CMs has been studied extensively for myocardial regeneration 
potential and in vitro tissue remodeling. One of the challenges in designing a functional cardiac tissue is well-defined cell contraction and alignment [219]. Cardiac patches should ideally be electrically conductive, mechanically robust and elastic, and prevascularized for functional integration into organ architecture resulting in improved contraction potential. Zhang and collaborators bioprinted a scaffold using an EC-laden bio-ink with sodium alginate and gelatin/methacylate (GelMA) seeded with CMs to create an endothelialized myocardium [220]. A rigid 3D structure was formed as a result of crosslinking of alginate with calcium ions followed by UV of the GelMA. Endothelial cells migrated towards periphery of the scaffold fibers and formed a confluent layer. Cardiomyocytes seeded into the scaffold with controlled anisotropy formed an aligned myocardium with contractions in a synchronous manner. This developed a functional myocardium with an interlacing endothelium and well-aligned cardiomyocytes.

Extensive research has been performed to replace infarcted cardiac tissue with tissueengineered cardiac patches made of biocompatible and bioabsorbable materials such as purified ECM molecules and heterogeneous mixtures of ECM components [221]. Jang and collaborators created a 3D prevascularized stem cell patch through spatial organization of cardiac progenitor/MSCs using decellularized ECM bio-ink [222]. The cardiac patch was shown to decrease cardiac remodeling and fibrosis and promoted cardiomyogenesis and neovascularization at the injured myocardium post transplantation. Gao et al. 3Dprinted an EPC/atorvastatin-loaded PLGA microspheres laden bioblood vessel and bio-ink composed of vascular tissue-derived ECM and alginate [223]. The engineered tissue revealed enhanced viability, proliferation, and differentiation of endothelial progenitor cells (EPCs) and endothelialization in vitro. In a nude mice hind limb ischemia model, the bioblood vessel (BBV)-based method showed significantly improved EPC function and recovery rates of ischemic injury. These studies illustrate the advancement of cardiac patches for preclinical testing.

\subsection{Organ-on-a-Chip}

Organ-on-a-chip engineering involves the microfabrication of artificial organs with tissue-engineered ECM and various types of cells to recapitulate morphogenesis, differentiation, and functions of the organ. Organ-on-a-chip models have the potential replicate key aspects of human physiology and revolutionize disease modeling, pharmacological studies, and pre-clinical drug development. The success of these tissue models critically depends on the functional assembly and human cell maturation that are building blocks on organ-on-a-chip systems, for example, assembly of human stem cell-derived CMs in a controlled microenvironment into a functional cardiac tissue.

Integration of 3D printing into organ-on-a-chip engineering can facilitate organ microfabrication with heterogeneity, a desired 3D cellular arrangement, tissue-specific functions, desired cellular arrangement, and mechanical and electrical components. ECM components have been extensively studied in vitro and in vivo for organ-on-chip engineering. The most abundant ECM component, the collagen fibrillar structure, assembles into a viscoelastic gel under physiological $\mathrm{pH}$, temperature, and ionic strength conditions that provides a cell-adhesive, supportive, and structural network. The mechanical properties of the gel can be tuned by adding crosslinkers (e.g., 1-ethyl-3-(3-dimethylaminopropyl)carbodiimide and n-hydroxysuccinimide) that makes collagen an attractive bio-ink for organ-on-a-chip applications [224]. Fibrin has been used in maintaining the 3D shape of the printed constructs due to its rapid gelation properties. Hinton and collaborators successfully printed whole brain and heart structures by dispensing collagen hydrogel containing fibrin and cellular components into a gelatin slurry bath with thrombin [225]. In another example, Olya and collaborators developed a 3D human cardiac fibrosis-on-a-chip (hCFon-a-chip) platform that recapitulated the distinctive characteristics of cardiac fibrosis and provided proof-of-principle for phenotypic analysis of a drug for treatment of idiopathic pulmonary fibrosis [226]. The group designed a human hCF-on-a-chip model to screen for possible biomarkers of human cardiac fibrosis. Additionally, the group used human 
iPSC-derived cardiomyocytes to study the pathophysiologically relevant capabilities of the human hCF-on-a-chip device, including cardiomyocyte functional analysis to unravel the understanding of disease progression for treating heart failure and cardiac fibrosis. $\mathrm{dECM}$ has been widely used in reproducing the natural environment of cells in native tissues [227]. These studies illustrate the applications of ECM-based biomaterials for organ-on-a-chip applications.

\section{Future Perspectives and Conclusions}

Despite the benefits of biocompatibility and low immunogenicity of ECM-based biomaterials for cardiovascular tissue engineering and regenerative medicine, a number of limitations hinder their clinical translation. First is the limited ability to control their mechanical properties. As an example, the structure of collagen scaffolds, either crosslinked or decellularized, is relatively fragile and temperature sensitive. Therefore, these biomaterials are generally not able to withstand physiological burst pressures. Improving mechanical properties by chemical modification (i.e., methacrylation [228,229]) or incorporation of polymers [230] and other proteins [231] can be beneficial. Second, the properties and composition of decellularized ECM may be inconsistent due to batch-to-batch variability [232]. To reduce batch variations, a single batch using pooled sources can reduce some of the variability. Another limitation is the inability to sterilize the scaffolds using conventional high-heat methods. Alternative sterilization methods using low-dose gamma irradiation $(\gamma-$ ray) alters the molecular structure and decreases the mechanical and enzymatic resistance of the collagen scaffold [233-236]. Additionally, ECM-based biomaterials have limited tunability of their degradation kinetics. For example, purified non-crosslinked collagen hydrogel injected into the myocardium persisted only for several days [237], whereas crosslinked high-density collagen scaffolds only partially degraded after seven weeks in porcine muscle [238].

The design of multi-component ECM scaffolds depends on the size and nature of the components. At the molecular level, integrating proteins and polysaccharides into a polymer synthetic hydrogel can impart biological functions and tunability in molecular architecture, chemical composition, and mechanical properties. At the microscopic level, the addition of micro or nano particles into hydrogels provides biological functions and mechanical characteristics. It allows for the spatiotemporal release of biologically active compounds for desired cellular functions. While hybrid approaches offer unprecedented opportunities for mimicking the complex native environment, there are challenges that need to be addressed These materials are inherently heterogenous, with chemical and structural variations that can complicate the engineering of hybrid scaffold. As the desired biological complexity increases, stability and consistency become challenging to achieve. New approaches for maintaining protein structure and function and particle synthesis will help design well-integrated hybrid materials with structural stability. Finally, immunogenic properties of new materials need to be studied concomitant with design of tissue engineered constructs. The translation of these advances to address biological challenges offers promising applications of these hybrid materials in tissue engineering.

Despite ECM-based biomaterials generally having low immunogenicity, it has been reported that the residual nucleic acids and cell membrane epitopes (i.e., galactose-alpha-1, 3 galactose) can trigger adverse immune response post implantation [10,11]. Modulating the immune response by incorporating immunosuppressive molecules (i.e., TGF $\beta 1$, IL10 [239]) anti-Fas antibodies [240,241], or gene-editing strategies [242] may partially address the concerns of immunogenicity. Despite these limitations, ECM-based biomaterials remain promising, and we anticipate the rise of ECM-based biomaterials being used in clinical applications of cardiovascular regeneration.

Author Contributions: Conceptualization, A.K. and N.F.H.; literature search, A.K., M.Z. and N.F.H.; writing - original draft preparation, A.K.; writing—review and editing, A.K., M.Z. and N.F.H.; funding acquisition, N.F.H. All authors have read and agreed to the published version of the manuscript. 
Funding: This work was supported in part by grants to NFH from the US National Institutes of Health (R01 HL127113, R01 HL142718, and P2CHD086843), the US Department of Veterans Affairs (1I01BX002310 and 1I01BX004259), the National Science Foundation (1829534), and the American Heart Association (20IPA35360085 and 20IPA35310731).

Institutional Review Board Statement: Not applicable.

Informed Consent Statement: Not applicable.

Conflicts of Interest: The authors declare no conflict of interest.

\section{References}

1. Reyna, M.A.; Sadr, N.; Perez Alday, E.A.; Gu, A.; Shah, A.; Robichaux, C.; Rab, A.B.; Elola, A.; Seyedi, S.; Ansari, S.; et al. Heart disease and stroke statistics-2021 update: A report from the American Heart Association. Circulation 2021, 143, e254-e743.

2. Yannas, I.V.; Burke, J.F.; Orgill, D.P.; Skrabut, E.M. Wound tissue can utilize a polymeric template to synthesize a functional extension of skin. Science 1982, 215, 174-176. [CrossRef] [PubMed]

3. Frantz, C.; Stewart, K.M.; Weaver, V.M. The extracellular matrix at a glance. J. Cell Sci. 2010, 123, 4195-4200. [CrossRef] [PubMed]

4. Reid, J.A.; Callanan, A. Hybrid cardiovascular sourced extracellular matrix scaffolds as possible platforms for vascular tissue engineering. J. Biomed. Mater. Res. Part B Appl. Biomater. 2020, 108, 910-924. [CrossRef]

5. Yue, B. Biology of the extracellular matrix: An overview. J. Glaucoma 2014, 23, S20-S23. [CrossRef]

6. Bissell, M.J.; Hall, H.G.; Parry, G. How does the extracellular matrix direct gene expression? J. Theor. Biol. 1982, 99, 31-68. [CrossRef]

7. Bornstein, P. Synthesis and secretion of structural macromolecules by endothelial cells in culture. Pathobiol. Endothel. Cell 1982, 215-228.

8. Schultz, G.S.; Davidson, J.M.; Kirsner, R.S.; Bornstein, P.; Herman, I.M. Dynamic reciprocity in the wound microenvironment. Wound Repair Regen. 2011, 19, 134-148. [CrossRef]

9. Russo, T.A.; Banuth, A.M.M.; Nader, H.B.; Dreyfuss, J.L. Altered shear stress on endothelial cells leads to remodeling of extracellular matrix and induction of angiogenesis. PLoS ONE 2020, 15, e0241040. [CrossRef]

10. Neve, A.; Cantatore, F.P.; Maruotti, N.; Corrado, A.; Ribatti, D. Extracellular Matrix Modulates Angiogenesis in Physiological and Pathological Conditions. BioMed Res. Int. 2014, 756078. [CrossRef]

11. Ahmed, M. Extracellular Matrix Regulation of Stem Cell Behavior. Curr. Stem Cell Rep. 2016, 2, 197-206. [CrossRef]

12. Gattazzo, F.; Urciuolo, A.; Bonaldo, P. Extracellular matrix: A dynamic microenvironment for stem cell niche. Biochim. Biophys. Acta (BBA)-Gen. Subj. 2014, 1840, 2506-2519. [CrossRef]

13. Sottile, J. Regulation of angiogenesis by extracellular matrix. Biochim. Biophys. Acta (BBA) Rev. Cancer 2004, 1654, 13-22. [CrossRef]

14. Schultz, G.S.; Wysocki, A. Interactions between extracellular matrix and growth factors in wound healing. Wound Repair Regen. 2009, 17, 153-162. [CrossRef]

15. Agren, M.S.; Werthen, M. The Extracellular Matrix in Wound Healing: A Closer Look at Therapeutics for Chronic Wounds. Int. J. Low. Extrem. Wounds 2007, 6, 82-97. [CrossRef]

16. Xue, M.; Jackson, C.J. Extracellular Matrix Reorganization During Wound Healing and Its Impact on Abnormal Scarring. Adv. Wound Care 2015, 4, 119-136. [CrossRef]

17. Sherwood, L. Human Physiology: From Cells to Systems; Cengage Learning: Belmont, CA, USA, 2015.

18. Fox, S.I. Fundamentals of Human Physiology; McGraw-Hill: New York, NY, USA, 2009.

19. Maton, A. Human Biology and Health; Prentice Hall: Hoboken, NJ, USA, 1997.

20. Stratman, A.N.; Yu, J.A.; Mulligan, T.S.; Butler, M.G.; Sause, E.T.; Weinstein, B.M. Chapter 24—Blood Vessel Formation. Principles of Developmental Genetics, 2nd ed.; Academic Press: Oxford, UK, 2015; pp. 421-449.

21. McMillan, D.B.; Harris, R.J. An Atlas of Comparative Vertebrate Histology; Academic Press: Cambridge, MA, USA, 2018.

22. Tucker, W.D.; Arora, Y.; Mahajan, K. Anatomy, Blood Vessels; StatPearls Publishing: Treasure Island, FL, USA, 2017.

23. Lacolley, P.; Regnault, V.; Nicoletti, A.; Li, Z.; Michel, J.-B. The vascular smooth muscle cell in arterial pathology: A cell that can take on multiple roles. Cardiovasc. Res. 2012, 95, 194-204. [CrossRef]

24. Cronenwett, J.L.; Johnston, K.W. Rutherford's Vascular Surgery e-Book; Elsevier Health Sciences: Amsterdam, The Netherlands, 2014.

25. Lüscher, T.; Predel, H.-G.; Yang, Z.; Bühler, F.; von Segesser, L.; Turina, M. Implications of pulsatile stretch on growth of saphenous vein and mammary artery smooth muscle. Lancet 1992, 340, 878-879. [CrossRef]

26. Wong, A.P.; Nili, N.; Strauss, B.H. In vitro differences between venous and arterial-derived smooth muscle cells: Potential modulatory role of decorin. Cardiovasc. Res. 2005, 65, 702-710. [CrossRef]

27. Deanfield, J.E.; Halcox, J.P.; Rabelink, T.J. Endothelial function and dysfunction: Testing and clinical relevance. Circulation 2007, 115, 1285-1295. [CrossRef]

28. Bennett, M.R.; Sinha, S.; Owens, G.K. Vascular Smooth Muscle Cells in Atherosclerosis. Circ. Res. 2016, 118, 692-702. [CrossRef]

29. Bergers, G.; Song, S. The role of pericytes in blood-vessel formation and maintenance. Neuro Oncol. 2005, 7, 452-464. [CrossRef]

30. Senger, D.R.; Davis, G.E. Angiogenesis. Cold Spring Harb. Perspect. Biol. 2011, 3, a005090. [CrossRef] 
31. Hussey, G.S.; Dziki, J.L.; Badylak, S.F. Extracellular matrix-based materials for regenerative medicine. Nat. Rev. Mater. 2018, 3, 159-173. [CrossRef]

32. Peppas, N.A.; Sahlin, J.J. Hydrogels as mucoadhesive and bioadhesive materials: A review. Biomaterials 1996, 17, 1553-1561. [CrossRef]

33. Hu, W.; Wang, Z.; Xiao, Y.; Zhang, S.; Wang, J. Advances in crosslinking strategies of biomedical hydrogels. Biomater. Sci. 2019, 7, 843-855. [CrossRef]

34. Nguyen, K.T.; West, J.L. Photopolymerizable hydrogels for tissue engineering applications. Biomaterials 2002, $23,4307-4314$. [CrossRef]

35. Wu, S.; Peng, S.; Wang, C.H. Multifunctional Polymer Nanocomposites Reinforced by Aligned Carbon Nanomaterials. Polymers 2018, 10, 542. [CrossRef]

36. Hennink, W.E.; van Nostrum, C.F. Novel crosslinking methods to design hydrogels. Adv. Drug Deliv. Rev. 2012, 64, 223-236. [CrossRef]

37. Yokoyama, F.; Masada, I.; Shimamura, K.; Ikawa, T.; Monobe, K. Morphology and structure of highly elastic poly (vinyl alcohol) hydrogel prepared by repeated freezing-and-melting. Colloid Polym. Sci. 1986, 264, 595-601. [CrossRef]

38. Eagland, D.; Crowther, N.J.; Butler, C.J. Complexation between polyoxyethylene and polymethacrylic acid-The importance of the molar mass of polyoxyethylene. Eur. Polym. J. 1994, 30, 767-773. [CrossRef]

39. Wichterle, O.; LÍM, D. Hydrophilic Gels for Biological Use. Nature 1960, 185, 117-118. [CrossRef]

40. Sperinde, J.J.; Griffith, L.G. Control and prediction of gelation kinetics in enzymatically cross-linked poly (ethylene glycol) hydrogels. Macromolecules 2000, 33, 5476-5480. [CrossRef]

41. Pomeroy, J.E.; Helfer, A.; Bursac, N. Biomaterializing the promise of cardiac tissue engineering. Biotechnol. Adv. 2020, $42,107353$. [CrossRef]

42. Patel, B.; Xu, Z.; Pinnock, C.B.; Kabbani, L.S.; Lam, M.T. Self-assembled Collagen-Fibrin Hydrogel Reinforces Tissue Engineered Adventitia Vessels Seeded with Human Fibroblasts. Sci. Rep. 2018, 8, 3294. [CrossRef]

43. Lee, F.; Kurisawa, M. Formation and stability of interpenetrating polymer network hydrogels consisting of fibrin and hyaluronic acid for tissue engineering. Acta Biomater. 2013, 9, 5143-5152. [CrossRef]

44. Xu, Q.; Torres, J.E.; Hakim, M.; Babiak, P.M.; Pal, P.; Battistoni, C.M.; Nguyen, M.; Panitch, A.; Solorio, L.; Liu, J.C. Collagen-and hyaluronic acid-based hydrogels and their biomedical applications. Mater. Sci. Eng. R Rep. 2021, 146, 100641. [CrossRef]

45. Kim, H.D.; Lee, E.A.; An, Y.H.; Kim, S.L.; Lee, S.S.; Yu, S.J.; Jang, H.L.; Nam, K.T.; Im, S.G.; Hwang, N.S. Chondroitin Sulfate-Based Biomineralizing Surface Hydrogels for Bone Tissue Engineering. ACS Appl. Mater. Interfaces 2017, 9, 21639-21650. [CrossRef]

46. Pacak, C.A.; MacKay, A.A.; Cowan, D.B. Au-Cowan. An Improved Method for the Preparation of Type I Collagen from Skin. JoVE 2014, 83, e51011.

47. Xing, H.; Lee, H.; Luo, L.; Kyriakides, T.R. Extracellular matrix-derived biomaterials in engineering cell function. Biotechnol. Adv. 2020, 42, 107421. [CrossRef]

48. Tharmalingam, T.; Sunley, K.; Spearman, M.; Butler, M. Enhanced Production of Human Recombinant Proteins from CHO cells Grown to High Densities in Macroporous Microcarriers. Mol. Biotechnol. 2011, 49, 263-276. [CrossRef]

49. Nagaoka, M.; Jiang, H.L.; Hoshiba, T.; Akaike, T.; Cho, C.S. Application of Recombinant Fusion Proteins for Tissue Engineering. Ann. Biomed. Eng. 2010, 38, 683-693. [CrossRef]

50. Kutty, J.K.; Cho, E.; Lee, J.S.; Vyavahare, N.R.; Webb, K. The effect of hyaluronic acid incorporation on fibroblast spreading and proliferation within PEG-diacrylate based semi-interpenetrating networks. Biomaterials 2007, 28, 4928-4938. [CrossRef]

51. Nakayama, K.H.; Surya, V.N.; Gole, M.; Walker, T.W.; Yang, W.; Lai, E.S.; Ostrowski, M.A.; Fuller, G.G.; Dunn, A.R.; Huang, N.F. Nanoscale patterning of extracellular matrix alters endothelial function under shear stress. Nano Lett. 2016, 16, 410-419. [CrossRef]

52. Nakayama, K.H.; Joshi, P.A.; Lai, E.S.; Gujar, P.; Joubert, L.-M.; Chen, B.; Huang, N.F. Bilayered vascular graft derived from human induced pluripotent stem cells with biomimetic structure and function. Regen. Med. 2015, 10, 745-755. [CrossRef]

53. Ozguldez, H.O.; Cha, J.; Hong, Y.; Koh, I.; Kim, P. Nanoengineered, cell-derived extracellular matrix influences ECM-related gene expression of mesenchymal stem cells. Biomater. Res. 2018, 22, 1-9. [CrossRef]

54. Smith, L.; Cho, S.; Discher, D.E. Stem cell differentiation is regulated by extracellular matrix mechanics. Physiology 2018, 33, 16-25. [CrossRef]

55. Pati, F.; Jang, J.; Ha, D.H.; Kim, S.W.; Rhie, J.W.; Shim, J.H.; Kim, D.H.; Cho, D.W. Printing three-dimensional tissue analogues with decellularized extracellular matrix bioink. Nat. Commun. 2014, 5, 1-11. [CrossRef]

56. Hou, L.; Coller, J.; Natu, V.; Hastie, T.J.; Huang, N.F. Combinatorial extracellular matrix microenvironments promote survival and phenotype of human induced pluripotent stem cell-derived endothelial cells in hypoxia. Acta Biomater. 2016, 44, 188-199. [CrossRef]

57. Huang, N.; Okogbaa, J.; Lee, J.; Jha, A.; Zaitseva, T.S.; Paukshto, M.V.; Sun, J.S.; Punjya, N.; Fuller, G.G.; Cooke, J.P. The modulation of endothelial cell morphology, function, and survival using anisotropic nanofibrillar collagen scaffolds. Biomaterials 2013, 34, 4038-4047. [CrossRef]

58. Lu, Y.Y.; Chen, Y.-C.; Kao, Y.-H.; Wu, T.-J.; Chen, S.-A.; Chen, Y.-J. Extracellular matrix of collagen modulates intracellular calcium handling and electrophysiological characteristics of HL-1 cardiomyocytes with activation of angiotensin II type 1 receptor. J. Card. Fail. 2011, 17, 82-90. [CrossRef] 
59. Schönberger, T.; Ziegler, M.; Borst, O.; Konrad, I.; Nieswandt, B.; Massberg, S.; Ochmann, C.; Jürgens, T.; Seizer, P.; Langer, H.; et al. The dimeric platelet collagen receptor GPVI-Fc reduces platelet adhesion to activated endothelium and preserves myocardial function after transient ischemia in mice. Am. J. Physiol. Physiol. 2012, 303, C757-C766. [CrossRef]

60. Zhang, W.; Kong, C.W.; Tong, M.H.; Chooi, W.H.; Huang, N.; Li, R.A.; Chan, B.P. Maturation of human embryonic stem cell-derived cardiomyocytes (hESC-CMs) in 3D collagen matrix: Effects of niche cell supplementation and mechanical stimulation. Acta Biomater. 2017, 49, 204-217. [CrossRef]

61. Bassat, E.; Mutlak, Y.E.; Genzelinakh, A.; Shadrin, I.; Umansky, K.B.; Yifa, O.; Kain, D.; Rajchman, D.; Leach, J.; Bassat, D.R.; et al. The extracellular matrix protein agrin promotes heart regeneration in mice. Nature 2017, 547, 179-184. [CrossRef]

62. Schenke-Layland, K.; Rhodes, K.E.; Angelis, E.; Butylkova, Y.; Heydarkhan-Hagvall, S.; Gekas, C.; Zhang, R.; Goldhaber, J.I.; Mikkola, H.K.; Plath, K.; et al. Reprogrammed Mouse Fibroblasts Differentiate into Cells of the Cardiovascular and Hematopoietic Lineages. Stem Cells 2008, 26, 1537-1546. [CrossRef]

63. Kaiser, N.J.; Kant, R.J.; Minor, A.J.; Coulombe, K.L. Optimizing Blended Collagen-Fibrin Hydrogels for Cardiac Tissue Engineering with Human iPSC-derived Cardiomyocytes. ACS Biomater. Sci. Eng. 2019, 5, 887-899. [CrossRef]

64. Fathi, A.; Mithieux, S.M.; Wei, H.; Chrzanowski, W.; Valtchev, P.; Weiss, A.S.; Dehghani, F. Elastin based cell-laden injectable hy-drogels with tunable gelation, mechanical and biodegradation properties. Biomaterials 2014, 35, 5425-5435. [CrossRef]

65. Wang, X.; Ali, M.S.; Lacerda, C.M.R. A Three-Dimensional Collagen-Elastin Scaffold for Heart Valve Tissue Engineering. Bioengineering 2018, 5, 69. [CrossRef]

66. Crapo, P.M.; Gilbert, T.; Badylak, S.F. An overview of tissue and whole organ decellularization processes. Biomaterials 2011, 32, 3233-3243. [CrossRef]

67. Keane, T.; Swinehart, I.T.; Badylak, S.F. Methods of tissue decellularization used for preparation of biologic scaffolds and in vivo relevance. Methods 2015, 84, 25-34. [CrossRef]

68. Kim, B.S.; Kim, H.; Gao, G.; Jang, J.; Cho, D.-W. Decellularized extracellular matrix: A step towards the next generation source for bioink manufacturing. Biofabrication 2017, 9, 034104. [CrossRef] [PubMed]

69. Gilbert, T.; Sellaro, T.L.; Badylak, S.F. Decellularization of tissues and organs. Biomaterials 2006, 27, 3675-3683. [CrossRef] [PubMed]

70. Das, S.; Jang, J. 3D bioprinting and decellularized ECM-based biomaterials for in vitro CV tissue engineering. J. 3D Print. Med. 2018, 2, 69-87. [CrossRef]

71. McFetridge, P.S.; Daniel, J.W.; Bodamyali, T.; Horrocks, M.; Chaudhuri, J.B. Preparation of porcine carotid arteries for vascular tissue engineering applications. J. Biomed. Mater. Res. 2004, 70A, 224-234. [CrossRef]

72. Sellaro, T.L.; Ravindra, A.K.; Stolz, D.B.; Badylak, S.F. Maintenance of Hepatic Sinusoidal Endothelial Cell PhenotypeIn VitroUsing Organ-Specific Extracellular Matrix Scaffolds. Tissue Eng. 2007, 13, 2301-2310. [CrossRef]

73. Bejleri, D.; Davis, M.E. Decellularized Extracellular Matrix Materials for Cardiac Repair and Regeneration. Adv. Healthc. Mater. 2019, 8, e1801217. [CrossRef]

74. Brown, B.N.; Badylak, S.F. Extracellular matrix as an inductive scaffold for functional tissue reconstruction. Transl. Res. 2013, 163, 268-285. [CrossRef]

75. Kim, M.; Hwang, D.G.; Jang, J. 3D Pancreatic Tissue Modeling in vitro: Advances and Prospects. BioChip J. 2020, 14, 84-99. [CrossRef]

76. Yi, H.-G.; Lee, H.; Cho, D.-W. 3D Printing of Organs-On-Chips. Bioengineering 2017, 4, 10. [CrossRef]

77. Taylor, D.A.; Sampaio, L.C.; Ferdous, Z.; Gobin, A.S.; Taite, L.J. Decellularized matrices in regenerative medicine. Acta Biomater. 2018, 74, 74-89. [CrossRef]

78. Serpooshan, V.; Zhao, M.; Metzler, S.A.; Wei, K.; Shah, P.B.; Wang, A.; Mahmoudi, M.; Malkovskiy, A.V.; Rajadas, J.; Butte, M.; et al. The effect of bioengineered acellular collagen patch on cardiac remodeling and ventricular function post myocardial infarction. Biomaterials 2013, 34, 9048-9055. [CrossRef]

79. Basara, G.; Ozcebe, S.; Ellis, B.; Zorlutuna, P. Tunable Human Myocardium Derived Decellularized Extracellular Matrix for 3D Bioprinting and Cardiac Tissue Engineering. Gels 2021, 7, 70. [CrossRef]

80. Simsa, R.; Padma, A.M.; Heher, P.; Hellström, M.; Teuschl, A.; Jenndahl, L.; Bergh, N.; Fogelstrand, P. Systematic in vitro comparison of decellu-larization protocols for blood vessels. PLoS ONE 2018, 13, e0209269. [CrossRef]

81. Kurokawa, S.; Hashimoto, Y.; Funamoto, S.; Murata, K.; Yamashita, A.; Yamazaki, K.; Ikeda, T.; Minatoya, K.; Kishida, A.; Masumoto, H. In vivo recellularization of xenogeneic vascular grafts decellularized with high hydrostatic pressure method in a porcine carotid arterial interpose model. PLoS ONE 2021, 16, e0254160. [CrossRef]

82. Karantalis, V.; Suncion-Loescher, V.Y.; Bagno, L.; Golpanian, S.; Wolf, A.; Sanina, C.; Premer, C.; Kanelidis, A.J.; McCall, F.; Wang, B.; et al. Synergistic Effects of Combined Cell Therapy for Chronic Ischemic Cardiomyopathy. J. Am. Coll. Cardiol. 2015, 66, 1990-1999. [CrossRef]

83. Spitzer, G.; Adkins, D.; Mathews, M.; Velasquez, W.; Bowers, C.; Dunphy, F.; Kronmueller, N.; Niemeyer, R.; McIntyre, W.; Petruska, P. Randomized comparison of G-CSF + GM-CSF vs G-CSF alone for mobilization of peripheral blood stem cells: Effects on hematopoietic recovery after high-dose chemotherapy. Bone Marrow Transplant. 1997, 20, 921-930. [CrossRef]

84. Ballotta, V.; Smits, A.I.; Driessen-Mol, A.; Bouten, C.V.; Baaijens, F.P. Synergistic protein secretion by mesenchymal stromal cells seeded in 3D scaffolds and circulating leukocytes in physiological flow. Biomaterials 2014, 35, 9100-9113. [CrossRef] 
85. Iwase, T.; Nagaya, N.; Fujii, T.; Itoh, T.; Murakami, S.; Matsumoto, T.; Kangawa, K.; Kitamura, S. Comparison of angiogenic potency between mesenchymal stem cells and mononuclear cells in a rat model of hindlimb ischemia. Cardiovasc. Res. 2005, 66, 543-551. [CrossRef]

86. Van Velthoven, C.T.; Kavelaars, A.; Heijnen, C.J. Mesenchymal stem cells as a treatment for neonatal ischemic brain damage. Pediatr. Res. 2012, 71, 474-481. [CrossRef]

87. Carvalho, M.S.; Silva, J.C.; Hoff, C.M.; Cabral, J.M.S.; Linhardt, R.J.; Da Silva, C.L.; Vashishth, D. Loss and rescue of osteocalcin and osteopontin modulate osteogenic and angiogenic features of mesenchymal stem/stromal cells. J. Cell. Physiol. 2020, 235, 7496-7515. [CrossRef]

88. Jehn, P.; Winterboer, J.; Kampmann, A.; Zimmerer, R.; Spalthoff, S.; Dittmann, J.; Gellrich, N.-C.; Tavassol, F. Angiogenic effects of mesenchymal stem cells in combination with different scaffold materials. Microvasc. Res. 2019, 127, 103925. [CrossRef]

89. Efraim, Y.; Sarig, H.; Anavy, N.C.; Sarig, U.; de Berardinis, E.; Chaw, S.-Y.; Krishnamoorthi, M.; Kalifa, J.; Bogireddi, H.; Duc, T.V.; et al. Biohybrid cardiac ECM-based hydrogels improve long term cardiac function post myocardial infarction. Acta Biomater. 2016, 50, 220-233. [CrossRef]

90. Jung, J.P.; Hu, D.; Domian, I.J.; Ogle, B.M. An integrated statistical model for enhanced murine cardiomyocyte differentiation via optimized engagement of 3D extracellular matrices. Sci. Rep. 2015, 5, 18705. [CrossRef]

91. Hirata, M.; Yamaoka, T. Effect of stem cell niche elasticity/ECM protein on the self-beating cardiomyocyte differentiation of induced pluripotent stem (iPS) cells at different stages. Acta Biomater. 2018, 65, 44-52. [CrossRef]

92. Tao, Z.-W.; Mohamed, M.; Hogan, M.; Gutierrez, L.; Birla, R.K. Optimizing a spontaneously contracting heart tissue patch with rat neonatal cardiac cells on fibrin gel. J. Tissue Eng. Regen. Med. 2014, 11, 153-163. [CrossRef]

93. Edalat, S.G.; Jang, Y.; Kim, J.; Park, Y. Collagen Type I Containing Hybrid Hydrogel Enhances Cardiomyocyte Maturation in a 3D Cardiac Model. Polymers 2019, 11, 687. [CrossRef]

94. Le, L.; Mohindra, P.; Fang, Q.; Sievers, R.E.; Mkrtschjan, M.A.; Solis-Ocampo, C.; Safranek, C.W.; Russell, B.; Lee, R.J.; Desai, T.A. Injectable hyaluronic acid based microrods provide local micromechanical and biochemical cues to attenuate cardiac fibrosis after myocardial infarction. Biomaterials 2018, 169, 11-21. [CrossRef]

95. French, K.M.; Maxwell, J.T.; Bhutani, S.; Ghosh-Choudhary, S.; Fierro, M.J.; Johnson, T.D.; Christman, K.L.; Taylor, W.R.; Davis, M.E. Fibronectin and Cyclic Strain Improve Cardiac Progenitor Cell Regenerative Potential In Vitro. Stem Cells Int. 2016, 2016, 1-11. [CrossRef]

96. Wainwright, J.M.; Czajka, C.A.; Patel, U.B.; Freytes, D.O.; Tobita, K.; Gilbert, T.; Badylak, S.F. Preparation of Cardiac Extracellular Matrix from an Intact Porcine Heart. Tissue Eng. Part C Methods 2010, 16, 525-532. [CrossRef]

97. Weymann, A.; Loganathan, S.; Takahashi, H.; Schies, C.; Claus, B.; Hirschberg, K.; Soós, P.; Korkmaz, S.; Schmack, B.; Karck, M.; et al. Development and Evaluation of a Perfusion Decellularization Porcine Heart Model-Generation of 3-Dimensional Myocardial Neoscaffolds. Circ. J. 2011, 75, 852-860. [CrossRef]

98. Akhyari, P.; Aubin, H.; Gwanmesia, P.; Barth, M.; Hoffmann, S.; Huelsmann, J.; Preuss, K.; Lichtenberg, A. The quest for an optimized protocol for whole-heart decellularization: A comparison of three popular and a novel decellularization technique and their diverse ef-fects on crucial extracellular matrix qualities. Tissue Eng. Part C Methods 2011, 17, 915-926. [CrossRef] [PubMed]

99. Grauss, R.W.; Hazekamp, M.G.; Oppenhuizen, F.; Van Munsterena, C.J.; Groot, A.C.G.-D.; DeRuiter, M.C. Histological evaluation of decellularised porcine aortic valves: Matrix changes due to different decellularisation methods. Eur. J. Cardio-Thoracic Surg. 2005, 27, 566-571. [CrossRef] [PubMed]

100. Gui, L.; Muto, A.; Chan, S.A.; Breuer, C.; Niklason, L.E. Development of Decellularized Human Umbilical Arteries as SmallDiameter Vascular Grafts. Tissue Eng. Part A 2009, 15, 2665-2676. [CrossRef] [PubMed]

101. Seifu, D.G.; Purnama, A.; Mequanint, K.; Mantovani, D. Small-diameter vascular tissue engineering. Nat. Rev. Cardiol. 2013, 10, 410-421. [CrossRef]

102. Shin, Y.J.; Shafranek, R.T.; Tsui, J.H.; Walcott, J.; Nelson, A.; Kim, D.H. 3D bioprinting of mechanically tuned bioinks derived from cardiac decellularized extracellular matrix. Acta Biomater. 2021, 119, 75-88. [CrossRef]

103. Tsui, J.H.; Leonard, A.; Camp, N.D.; Long, J.T.; Nawas, Z.Y.; Chavanachat, R.; Smith, A.S.; Choi, J.S.; Dong, Z.; Ahn, E.H.; et al Tunable electroconductive decellularized extracellular matrix hydrogels for engineering human cardiac microphysiological systems. Biomaterials 2021, 272, 120764. [CrossRef]

104. Das, S.; Kim, S.-W.; Choi, Y.-J.; Lee, S.; Lee, S.-H.; Kong, J.-S.; Park, H.-J.; Cho, D.-W.; Jang, J. Decellularized extracellular matrix bioinks and the external stimuli to enhance cardiac tissue development in vitro. Acta Biomater. 2019, 95, 188-200. [CrossRef]

105. Akbay, E.; Onur, M.A. Investigation of survival and migration potential of differentiated cardiomyocytes transplanted with decellularized heart scaffold. J. Biomed. Mater. Res. Part A 2018, 107, 561-570. [CrossRef]

106. Cheng, H.-W.; Tsui, Y.-K.; Cheung, K.M.; Chan, D.; Chan, B.P. Decellularization of Chondrocyte-Encapsulated Collagen Microspheres: A Three-Dimensional Model to Study the Effects of Acellular Matrix on Stem Cell Fate. Tissue Eng. Part C Methods 2009, 15, 697-706. [CrossRef]

107. Choi, K.-H.; Choi, B.H.; Park, S.R.; Kim, B.J.; Min, B.-H. The chondrogenic differentiation of mesenchymal stem cells on an extracellular matrix scaffold derived from porcine chondrocytes. Biomaterials 2010, 31, 5355-5365. [CrossRef]

108. Liao, J.; Guo, X.; Grande-Allen, K.J.; Kasper, F.; Mikos, A.G. Bioactive polymer/extracellular matrix scaffolds fabricated with a flow perfusion bioreactor for cartilage tissue engineering. Biomaterials 2010, 31, 8911-8920. [CrossRef] 
109. Wolchok, J.C.; Tresco, P.A. The isolation of cell derived extracellular matrix constructs using sacrificial open-cell foams. Biomaterials 2010, 31, 9595-9603. [CrossRef]

110. Lu, H.; Hoshiba, T.; Kawazoe, N.; Chen, G. Autologous extracellular matrix scaffolds for tissue engineering. Biomaterials 2011, 32, 2489-2499. [CrossRef]

111. Alberts, B. Cell Biology: The Endless Frontier. Mol. Biol. Cell 2010, 21, 3785. [CrossRef]

112. Xu, J.; Shi, G.-P. Vascular wall extracellular matrix proteins and vascular diseases. Biochim. Biophys. Acta (BBA) Mol. Basis Dis. 2014, 1842, 2106-2119. [CrossRef]

113. Yap, L.; Tay, H.G.; Nguyen, M.T.; Tjin, M.S.; Tryggvason, K. Laminins in Cellular Differentiation. Trends Cell Biol. 2019, 29, 987-1000. [CrossRef]

114. Nguyen, M.T.; Okina, E.; Chai, X.; Tan, K.H.; Hovatta, O.; Ghosh, S.; Tryggvason, K. Differentiation of Human Embryonic Stem Cells to Endothelial Progenitor Cells on Laminins in Defined and Xeno-free Systems. Stem Cell Rep. 2016, 7, 802-816. [CrossRef]

115. Stamati, K.; Priestley, J.V.; Mudera, V.; Cheema, U. Laminin promotes vascular network formation in 3D in vitro collagen scaffolds by regulating VEGF uptake. Exp. Cell Res. 2014, 327, 68-77. [CrossRef]

116. Davis, G.E.; Senger, D.R. Endothelial Extracellular Matrix. Circ. Res. 2005, 97, 1093-1107. [CrossRef]

117. Watt, F.M.; Huck, W.T.S. Role of the extracellular matrix in regulating stem cell fate. Nat. Rev. Mol. Cell Biol. 2013, 14, 467-473. [CrossRef]

118. Hou, L.; Kim, J.J.; Wanjare, M.; Patlolla, B.; Coller, J.; Natu, V.; Hastie, T.J.; Huang, N.F. Combinatorial Extracellular Matrix Microenvironments for Probing Endothelial Differentiation of Human Pluripotent Stem Cells. Sci. Rep. 2017, 7, 6551. [CrossRef]

119. Stratman, A.N.; Saunders, W.B.; Sacharidou, A.; Koh, W.; Fisher, K.E.; Zawieja, D.C.; Davis, M.J.; Davis, G.E. Endothelial cell lumen and vascular guidance tunnel formation requires MT1-MMP-dependent proteolysis in 3-dimensional collagen matrices. Blood 2009, 114, 237-247. [CrossRef]

120. Monchaux, E.; Vermette, P. Effects of surface properties and bioactivation of biomaterials on endothelial cells. Front. Biosci. 2009, 2, 239-255.

121. Daum, R.; Visser, D.; Wild, C.; Kutuzova, L.; Schneider, M.; Lorenz, G.; Weiss, M.; Hinderer, S.; Stock, U.A.; Seifert, M.; et al. Fibronectin Adsorption on Electrospun Synthetic Vascular Grafts Attracts Endothelial Progenitor Cells and Promotes Endothelialization in Dynamic In Vitro Culture. Cells 2020, 9, 778. [CrossRef]

122. Wang, L.-S.; Lee, F.; Lim, J.; Du, C.; Wan, A.C.; Lee, S.S.; Kurisawa, M. Enzymatic conjugation of a bioactive peptide into an injectable hyaluronic acid-tyramine hydrogel system to promote the formation of functional vasculature. Acta Biomater. 2014, 10, 2539-2550. [CrossRef]

123. Ning, L.-J.; Zhang, Y.-J.; Zhang, Y.; Qing, Q.; Jiang, Y.-L.; Yang, J.-L.; Luo, J.-C.; Qin, T.-W. The utilization of decellularized tendon slices to provide an inductive microenvironment for the proliferation and tenogenic differentiation of stem cells. Biomaterials 2015, 52, 539-550. [CrossRef]

124. Guo, G.; Jin, L.; Wu, B.; He, H.; Yang, F.; Xu, L.; Lei, Y.; Wang, Y. A method for simultaneously crosslinking and functionalizing extracellular matrix-based biomaterials as bioprosthetic heart valves with enhanced endothelialization and reduced inflammation. Acta Biomater. 2020, 119, 89-100. [CrossRef]

125. Ding, Y.; Yang, M.; Yang, Z.; Luo, R.; Lu, X.; Huang, N.; Huang, P.; Leng, Y. Cooperative control of blood compatibility and re-endothelialization by immobilized heparin and substrate topography. Acta Biomater. 2015, 15, 150-163. [CrossRef]

126. Filová, E.; Brynda, E.; Riedel, T.; Chlupáč, J.; Vandrovcová, M.; Švindrych, Z.; Lisá, V.; Houska, M.; Pirk, J.; Bačáková, L. Improved adhesion and differentiation of endothelial cells on surface-attached fibrin structures containing extracellular matrix proteins. $J$. Biomed. Mater. Res. Part A 2013, 102, 698-712. [CrossRef]

127. Caiado, F.; Carvalho, T.; Silva, F.; Castro, C.; Clode, N.; Dye, J.F.; Dias, S. The role of fibrin E on the modulation of endothelial progenitors adhesion, differentiation and angiogenic growth factor production and the promotion of wound healing. Biomaterials 2011, 32, 7096-7105. [CrossRef]

128. Kang, D.; Kim, J.H.; Jeong, Y.H.; Kwak, J.Y.; Yoon, S.; Jin, S. Endothelial monolayers on collagen-coated nanofibrous membranes: Cell-cell and cell-ECM interactions. Biofabrication 2016, 8, 025008. [CrossRef] [PubMed]

129. Liu, H.; Lin, J.; Roy, K. Effect of 3D scaffold and dynamic culture condition on the global gene expression profile of mouse embryonic stem cells. Biomaterials 2006, 27, 5978-5989. [CrossRef] [PubMed]

130. VanWinkle, W.B.; Snuggs, M.B.; Buja, L.M. Cardiogel: A biosynthetic extracellular matrix for cardiomyocyte culture In Vitro. Cell. Dev. Biol.-Anim. 1996, 32, 478-485. [CrossRef] [PubMed]

131. Uchida, N.; Sivaraman, S.; Amoroso, N.J.; Wagner, W.R.; Nishiguchi, A.; Matsusaki, M.; Akashi, M.; Nagatomi, J. Nanometer-sized extracellular matrix coating on polymer-based scaffold for tissue engineering applications. J. Biomed. Mater. Res. Part A 2015, 104, 94-103. [CrossRef] [PubMed]

132. Maia, F.R.; Fonseca, K.B.; Rodrigues, G.; Granja, P.L.; Barrias, C.C. Matrix-driven formation of mesenchymal stem cell-extracellular matrix microtissues on soft alginate hydrogels. Acta Biomater. 2014, 10, 3197-3208. [CrossRef]

133. Bonnans, C.; Chou, J.; Werb, Z. Remodelling the extracellular matrix in development and disease. Nat. Rev. Mol. Cell Biol. 2014, 15, 786-801. [CrossRef]

134. Foster, A.A.; Dewi, R.E.; Cai, L.; Hou, L.; Strassberg, Z.; Alcazar, C.A.; Heilshorn, S.C.; Huang, N.F. Protein-engineered hydrogels enhance the survival of induced pluripotent stem cell-derived endothelial cells for treatment of peripheral arterial disease. Biomater. Sci. 2018, 6, 614-622. [CrossRef] 
135. Sun, T.; Shi, Q.; Huang, Q.; Wang, H.; Xiong, X.; Hu, C.; Fukuda, T. Magnetic alginate microfibers as scaffolding elements for the fabrication of microvascular-like structures. Acta Biomater. 2017, 66, 272-281. [CrossRef]

136. Benning, L.; Gutzweiler, L.; Tröndle, K.; Riba, J.; Zengerle, R.; Koltay, P.; Zimmermann, S.; Stark, G.B.; Finkenzeller, G. Cytocompatibility testing of hydrogels toward bioprinting of mesenchymal stem cells. J. Biomed. Mater. Res. Part A 2017, 105, 3231-3241. [CrossRef]

137. Suri, S.; Schmidt, C.E. Photopatterned collagen-hyaluronic acid interpenetrating polymer network hydrogels. Acta Biomater. 2009, 5, 2385-2397. [CrossRef]

138. Duan, Y.; Liu, Z.; O’Neill, J.; Wan, L.Q.; Freytes, D.O.; Vunjak-Novakovic, G. Hybrid gel composed of native heart matrix and collagen induces cardiac differentiation of human embryonic stem cells without supplemental growth factors. J. Cardiovasc. Transl. Res. 2011, 4, 605. [CrossRef]

139. Shakouri-Motlagh, A.; O'Connor, A.J.; Brennecke, S.P.; Kalionis, B.; Heath, D.E. Native and solubilized decellularized extracellular matrix: A critical assessment of their potential for improving the expansion of mesenchymal stem cells. Acta Biomater. 2017, 55, 1-12. [CrossRef]

140. Candiello, J.; Grandhi, T.S.P.; Goh, S.K.; Vaidya, V.; Lemmon-Kishi, M.; Eliato, K.R.; Ros, R.; Kumta, P.N.; Rege, K.; Banerjee, I. 3D heterogeneous islet organoid generation from human embryonic stem cells using a novel engineered hydrogel platform. Biomaterials 2018, 177, 27-39. [CrossRef]

141. Giobbe, G.G.; Crowley, C.; Luni, C.; Campinoti, S.; Khedr, M.; Kretzschmar, K.; De Santis, M.M.; Zambaiti, E.; Michielin, F.; Meran, L.; et al. Extracellular matrix hydrogel derived from decellularized tissues enables endodermal organoid culture. Nat. Commun. 2019, 10, 1-14. [CrossRef]

142. Ghosh, K.; Pan, Z.; Guan, E.; Ge, S.; Liu, Y.; Nakamura, T.; Ren, X.-D.; Rafailovich, M.; Clark, R.A. Cell adaptation to a physiologically relevant ECM mimic with different viscoelastic properties. Biomaterials 2007, 28, 671-679. [CrossRef]

143. Dziki, J.L.; Badylak, S.F. Extracellular Matrix for Myocardial Repair. Adv. Exp. Med. Biol. 2018, 151-171. [CrossRef]

144. Drury, J.L.; Mooney, D. Hydrogels for tissue engineering: Scaffold design variables and applications. Biomaterials 2003, 24, 4337-4351. [CrossRef]

145. Francis, R.; Kumar, D.S. Biomedical Applications of Polymeric Materials and Composites; John Wiley \& Sons: Hoboken, NJ, USA, 2016.

146. Brigham, M.D.; Bick, A.; Lo, E.; Bendali, A.; Burdick, J.A.; Khademhosseini, A. Mechanically Robust and Bioadhesive Collagen and Photocrosslinkable Hyaluronic Acid Semi-Interpenetrating Networks. Tissue Eng. Part A 2009, 5, 1645-1653. [CrossRef]

147. Kleinman, H.K.; Martin, G.R. Matrigel: Basement membrane matrix with biological activity. Semin. Cancer Biol. 2005, 15, 378-386. [CrossRef]

148. Malda, J.; Visser, J.; Melchels, F.P.; Jüngst, T.; Hennink, W.E.; Dhert, W.; Groll, J.; Hutmacher, D.W. 25th Anniversary Article: Engineering Hydrogels for Biofabrication. Adv. Mater. 2013, 25, 5011-5028. [CrossRef]

149. Murphy, S.V.; Atala, A. 3D bioprinting of tissues and organs. Nat. Biotechnol. 2014, 32, 773-785. [CrossRef]

150. Colly, A.; Marquette, C.; Courtial, E.-J. Poloxamer/Poly(ethylene glycol) Self-Healing Hydrogel for High-Precision Freeform Reversible Embedding of Suspended Hydrogel. Langmuir 2021, 37, 4154-4162. [CrossRef]

151. Xavier, J.R.; Thakur, T.; Desai, P.; Jaiswal, M.K.; Sears, N.; Cosgriff-Hernandez, E.; Kaunas, R.; Gaharwar, A. Bioactive Nanoengineered Hydrogels for Bone Tissue Engineering: A Growth-Factor-Free Approach. ACS Nano 2015, 9, 3109-3118. [CrossRef]

152. Gaharwar, A.; Rivera, C.P.; Wu, C.-J.; Schmidt, G. Transparent, elastomeric and tough hydrogels from poly(ethylene glycol) and silicate nanoparticles. Acta Biomater. 2011, 7, 4139-4148. [CrossRef]

153. Peak, C.W.; Carrow, J.K.; Thakur, A.; Singh, A.; Gaharwar, A.K. Elastomeric Cell-Laden Nanocomposite Microfibers for Engineering Complex Tissues. Cell. Mol. Bioeng. 2015, 8, 404-415. [CrossRef]

154. Kang, H.W.; Lee, S.J.; Ko, I.K.; Kengla, C.; Yoo, J.J.; Atala, A. A 3D bioprinting system to produce human-scale tissue constructs with structural integrity. Nat. Biotechnol. 2016, 34, 312-319. [CrossRef]

155. Gasperini, L.; Mano, J.F.; Reis, R.L. Natural polymers for the microencapsulation of cells. J. R. Soc. Interface 2014, $11,20140817$. [CrossRef] [PubMed]

156. Chimene, D.; Lennox, K.K.; Kaunas, R.R.; Gaharwar, A.K. Advanced Bioinks for 3D Printing: A Materials Science Perspective. Ann. Biomed. Eng. 2016, 44, 2090-2102. [CrossRef]

157. Grover, G.N.; Rao, N.; Christman, K.L. Myocardial matrix-polyethylene glycol hybrid hydrogels for tissue engineering. Nanotechnology 2013, 25, 014011. [CrossRef]

158. Mintz, B.R.; Cooper, J.A., Jr. Hybrid hyaluronic acid hydrogel/poly ( $\varepsilon$-caprolactone) scaffold provides mechanically favorable platform for cartilage tissue engineering studies. J. Biomed. Mater. Res. Part A 2014, 102, 2918-2926. [CrossRef] [PubMed]

159. Geckil, H.; Xu, F.; Zhang, X.; Moon, S.; Demirci, U. Engineering hydrogels as extracellular matrix mimics. Nanomedicine 2010, 5, 469-484. [CrossRef] [PubMed]

160. Vega, S.; Kwon, M.; Burdick, J. Recent advances in hydrogels for cartilage tissue engineering. Eur. Cells Mater. 2017, 33 , 59-75. [CrossRef] [PubMed]

161. Guo, Y.; Yuan, T.; Xiao, Z.; Tang, P.; Xiao, Y.; Fan, Y.; Zhang, X. Hydrogels of collagen/chondroitin sulfate/hyaluronan interpenetrating polymer network for cartilage tissue engineering. J. Mater. Sci. Mater. Med. 2012, 23, 2267-2279. [CrossRef] [PubMed] 
162. Kérourédan, O.; Bourget, J.-M.; Rémy, M.; Crauste-Manciet, S.; Kalisky, J.; Catros, S.; Thébaud, N.B.; Devillard, R. Micropatterning of endothelial cells to create a capillary-like network with defined architecture by laser-assisted bioprinting. J. Mater. Sci. Mater. Med. 2019, 30, 1-12. [CrossRef]

163. Baker, B.M.; Chen, C.S. Deconstructing the third dimension-How 3D culture microenvironments alter cellular cues. J. Cell Sci. 2012, 125, 3015-3024. [CrossRef]

164. Huang, N.F.; Lee, R.J.; Li, S. Chemical and physical regulation of stem cells and progenitor cells: Potential for cardio-vascular tissue engineering. Tissue Eng. 2007, 13, 1809-1823. [CrossRef]

165. O'Neill, C.; Jordan, P.; Ireland, G. Evidence for two distinct mechanisms of anchorage stimulation in freshly explanted and 3T3 Swiss mouse fibroblasts. Cell 1986, 44, 489-496. [CrossRef]

166. Kane, R.S.; Takayama, S.; Ostuni, E.; Ingber, D.E.; Whitesides, G.M. Patterning Proteins and Cells Using Soft Lithography, The Bio-Materials: Silver Jubilee Compendium; Elsevier: Amsterdam, The Netherlands, 2006.

167. Whitesides, G.M.; Ostuni, E.; Takayama, S.; Jiang, X.; Ingber, D.E. Soft Lithography in Biology and Biochemistry. Annu. Rev. Biomed. Eng. 2001, 3, 335-373. [CrossRef]

168. Wanjare, M.; Hou, L.; Nakayama, K.H.; Kim, J.J.; Mezak, N.P.; Abilez, O.J.; Tzatzalos, E.; Wu, J.C.; Huang, N.F. Anisotropic microfibrous scaffolds enhance the organization and function of cardiomyocytes derived from induced pluripotent stem cells. Biomater. Sci. 2017, 5, 1567-1578. [CrossRef]

169. Murugan, R.; Ramakrishna, S. Design Strategies of Tissue Engineering Scaffolds with Controlled Fiber Orientation. Tissue Eng. 2007, 13, 1845-1866. [CrossRef]

170. Di Cio, S.; Bøggild, T.M.; Connelly, J.; Sutherland, D.S.; Gautrot, J.E. Differential integrin expression regulates cell sensing of the matrix nanoscale geometry. Acta Biomater. 2017, 50, 280-292. [CrossRef]

171. Lai, E.S.; Anderson, C.M.; Fuller, G.G. Designing a tubular matrix of oriented collagen fibrils for tissue engineering. Acta Biomater 2011, 7, 2448-2456. [CrossRef]

172. McWhorter, F.Y.; Wang, T.; Nguyen, P.; Chung, T.; Liu, W.F. Modulation of macrophage phenotype by cell shape. Proc. Natl. Acad. Sci. USA 2013, 110, 17253-17258. [CrossRef]

173. Chen, S.; Kawazoe, N.; Chen, G. Biomimetic Assembly of Vascular Endothelial Cells and Muscle Cells in Microgrooved Collagen Po-rous Scaffolds. Tissue Eng. Part C Methods 2017, 23, 367-376. [CrossRef]

174. Hudlicka, O. What makes blood vessels grow? J. Physiol. 1991, 444, 1-24. [CrossRef]

175. Wells, R.G. The role of matrix stiffness in regulating cell behavior. Hepatology 2008, 47, 1394-1400. [CrossRef]

176. Xie, S.-A.; Zhang, T.; Wang, J.; Zhao, F.; Zhang, Y.-P.; Yao, W.-J.; Hur, S.S.; Yeh, Y.-T.; Pang, W.; Zheng, L.-S.; et al. Matrix stiffness determines the phenotype of vascular smooth muscle cell in vitro and in vivo: Role of DNA methyltransferase 1 . Biomaterials 2018, 155, 203-216. [CrossRef]

177. Qiu, Y.; Bayomy, A.F.; Gomez, M.V.; Bauer, M.; Du, P.; Yang, Y.; Zhang, X.; Liao, R. A role for matrix stiffness in the regulation of cardiac side population cell function. Am. J. Physiol. Circ. Physiol. 2015, 308, H990-H997. [CrossRef]

178. Kural, M.H.; Billiar, K.L. Regulating tension in three-dimensional culture environments. Exp. Cell Res. 2013, 319, $2447-2459$. [CrossRef]

179. Emerman, J.T.; Burwen, S.J.; Pitelka, D.R. Substrate properties influencing ultrastructural differentiation of mammary epithelial cells in culture. Tissue Cell 1979, 11, 109-119. [CrossRef]

180. Boudreau, N.; Werb, Z.; Bissell, M.J. Suppression of apoptosis by basement membrane requires three-dimensional tissue organization and withdrawal from the cell cycle. Proc. Natl. Acad. Sci. USA 1996, 93, 3509-3513. [CrossRef]

181. Roskelley, C.D.; Desprez, P.Y.; Bissell, M.J. Extracellular matrix-dependent tissue-specific gene expression in mammary epithelial cells requires both physical and biochemical signal transduction. Proc. Natl. Acad. Sci. USA 1994, 91, 12378-12382. [CrossRef]

182. Farmer, S.R.; Ben-Ze'ev, A.; Benecke, B.J.; Penman, S. Altered translatability of messenger RNA from suspended anchoragedependent fibroblasts: Reversal upon cell attachment to a surface. Cell 1978, 15, 627-637. [CrossRef]

183. Edwards, W.S.; Mohtashemi, M.; Holdefer, W.F. The importance of proper caliber of lumen in femoral popliteal arterial reconstruction. J. Cardiovasc. Surg. 1967, 8, 195-197.

184. Hess, C.N.; Lopes, R.D.; Gibson, C.M.; Hager, R.; Wojdyla, D.M.; Englum, B.; Mack, M.J.; Califf, R.M.; Kouchoukos, N.T.; Peterson, E.D.; et al. Saphenous Vein Graft Failure After Coronary Artery Bypass Surgery. Circulation 2014, 130, 1445-1451. [CrossRef]

185. Angelini, G.D.; Breckenridge, I.M.; Butchart, E.G.; Armistead, S.H.; Middleton, K.M.; Henderson, A.H.; Newby, A.C. Metabolic damage to human saphenous vein during preparation for coronary artery bypass grafting. Cardiovasc. Res. 1985, 19, 326-334. [CrossRef]

186. McKavanagh, P.; Yanagawa, B.; Zawadowski, G.; Cheema, A. Management and Prevention of Saphenous Vein Graft Failure: A Review. Cardiol. Ther. 2017, 6, 203-223. [CrossRef]

187. Roll, S.; Müller-Nordhorn, J.; Keil, T.; Scholz, H.; Eidt, D.; Greiner, W.; Willich, S.N. Dacron ${ }^{\circledR}$ vs. PTFE as bypass materials in peripheral vascular surgery—Systematic review and meta-analysis. BMC Surg. 2008, 8, 22. [CrossRef]

188. Toursarkissian, B.; Eisenberg, P.R.; Abendschein, D.R.; Rubin, B.G. Thrombogenicity of small-diameter prosthetic grafts: Relative contributions of graft-associated thrombin and factor Xa. J. Vasc. Surg. 1997, 25, 730-735. [CrossRef]

189. Lin, P.H.; Chen, C.; Bush, R.L.; Yao, Q.; Lumsden, A.B.; Hanson, S.R. Small-caliber heparin-coated ePTFE grafts reduce platelet deposition and neointimal hyperplasia in a baboon model. J. Vasc. Surg. 2004, 39, 1322-1328. [CrossRef]

190. Kidson, I.G.; Abbott, W.M. Low compliance and arterial graft occlusion. Circulation 1978, 58, I1-I4. [PubMed] 
191. Aussel, A.; Thébaud, N.B.; Bérard, X.; Brizzi, V.; Delmond, S.; Bareille, R.; Siadous, R.; James, C.; Ripoche, J.; Durand, M.; et al. Chitosan-based hydrogels for developing a small-diameter vascular graft: In vitro and in vivo evaluation. Biomed. Mater. 2017, 12, 065003. [CrossRef] [PubMed]

192. Bracaglia, L.G.; Messina, M.; Winston, S.; Kuo, C.-Y.; Lerman, M.; Fisher, J.P. 3D Printed Pericardium Hydrogels to Promote Wound Healing in Vascular Applications. Biomacromolecules 2017, 18, 3802-3811. [CrossRef] [PubMed]

193. Nair, P.; Thottappillil, N. Scaffolds in vascular regeneration: Current status. Vasc. Health Risk Manag. 2015, 11, 79-91. [CrossRef]

194. Niklason, L.E.; Gao, J.; Abbott, W.M.; Hirschi, K.K.; Houser, S.; Marini, R.; Langer, R. Functional Arteries Grown in Vitro. Science 1999, 284, 489-493. [CrossRef]

195. Niklason, L.E.; Abbott, W.; Gao, J.; Klagges, B.; Hirschi, K.K.; Ulubayram, K.; Conroy, N.; Jones, R.; Vasanawala, A.; Sanzgiri, S.; et al. Morphologic and mechanical characteristics of engineered bovine arteries. J. Vasc. Surg. 2001, 33, 628-638. [CrossRef]

196. Quint, C.; Kondo, Y.; Manson, R.J.; Lawson, J.H.; Dardik, A.; Niklason, L.E. Decellularized tissue-engineered blood vessel as an arterial conduit. Proc. Natl. Acad. Sci. USA 2011, 108, 9214-9219. [CrossRef]

197. Dahl, S.L.M.; Kypson, A.P.; Lawson, J.H.; Blum, J.L.; Strader, J.T.; Li, Y.; Manson, R.J.; Tente, W.E.; DiBernardo, L.; Hensley, M.T.; et al. Readily Available Tissue-Engineered Vascular Grafts. Sci. Transl. Med. 2011, 3, 68ra9. [CrossRef]

198. Lawson, J.H.; Glickman, M.H.; Ilzecki, M.; Jakimowicz, T.; Jaroszynski, A.; Peden, E.K.; Pilgrim, A.J.; Prichard, H.L.; Guziewicz, M.; Przywara, S.; et al. Bioengineered human acellular vessels for dialysis access in patients with end-stage renal disease: Two phase 2 single-arm trials. Lancet 2016, 387, 2026-2034. [CrossRef]

199. Dahl, S.L.M.; Rhim, C.; Song, Y.C.; Niklason, L.E. Mechanical Properties and Compositions of Tissue Engineered and Native Arteries. Ann. Biomed. Eng. 2007, 35, 348-355. [CrossRef]

200. Beamish, J.A.; He, P.; Kottke-Marchant, K.; Marchant, R.E. Molecular Regulation of Contractile Smooth Muscle Cell Phenotype: Implications for Vascular Tissue Engineering. Tissue Eng. Part B Rev. 2010, 16, 467-491. [CrossRef]

201. Yamamoto, M.; Yamamoto, K.; Noumura, T. Type I Collagen Promotes Modulation of Cultured Rabbit Arterial Smooth Muscle Cells from a Contractile to a Synthetic Phenotype. Exp. Cell Res. 1993, 204, 121-129. [CrossRef]

202. Khanna, A. Fabrication of Human Serum Albumin Film for Enhanced Hemocompatibility and Mitigation of Intimal Hyperplasia under Physiologically Relevant Flow Shear Conditions. Ph.D. Thesis, Clemson University, Clemson, SC, USA, 2017.

203. Khanna, A. Fabrication of Human Serum Albumin film on expanded polytetrafluoroethylene (e-PTFE) for Enhanced Hemocompatibility and Adhesion Strength. In Proceedings of the Transactions of the 41st Annual Meeting of Society for Biomaterials (SFB), Minneapolis, MN, USA, 5-8 April 2017.

204. Lu, X.; Khanna, A.; Luzinov, I.; Nagatomi, J.; Harman, M. Surface modification of polypropylene surgical meshes for improving adhesion with poloxamine hydrogel adhesive. J. Biomed. Mater. Res. Part B Appl. Biomater. 2019, 107, 1047-1055. [CrossRef]

205. Koobatian, M.T.; Row, S.; Smith, R.J., Jr.; Koenigsknecht, C.; Andreadis, S.T.; Swartz, D.D. Successful endothelialization and remodeling of a cell-free small-diameter arterial graft in a large animal model. Biomaterials 2015, 76, 344-358. [CrossRef]

206. Roeder, R.; Wolfe, J.; Lianakis, N.; Hinson, T.; Geddes, L.A.; Obermiller, J. Compliance, elastic modulus, and burst pressure of small-intestine submucosa (SIS), small-diameter vascular grafts. J. Biomed. Mater. Res. 1999, 47, 65-70. [CrossRef]

207. Coakley, D.N.M.; Shaikh, F.; O'Sullivan, K.; Kavanagh, E.G.; Grace, P.; Walsh, S.; McGloughlin, T. Comparing the endothelialisation of extracellular matrix bioscaffolds with coated synthetic vascular graft materials. Int. J. Surg. 2015, 25, 31-37. [CrossRef]

208. Peng, H.; Schlaich, E.M.; Row, S.; Andreadis, S.T.; Swartz, D.D. A Novel Ovine ex vivo Arteriovenous Shunt Model to Test Vascular Implantability. Cells Tissues Organs 2012, 195, 108-121. [CrossRef]

209. Nasiri, B.; Row, S.; Smith, R.J., Jr.; Swartz, D.D.; Andreadis, S.T. Cell-Free Vascular Grafts That Grow with the Host. Adv. Funct. Mater. 2020, 30, 2005769. [CrossRef]

210. Row, S.; Peng, H.; Schlaich, E.M.; Koenigsknecht, C.; Andreadis, S.T.; Swartz, D.D. Arterial grafts exhibiting unprecedented cellular infiltration and remodeling in vivo: The role of cells in the vascular wall. Biomaterials 2015, 50, 115-126. [CrossRef]

211. Han, B.; Xue, F.; Fan, C.; Mo, X. Surface heparinization and blood compatibility modification of small intestinal submucosa (SIS) for small-caliber vascular regeneration. Bio-Med. Mater. Eng. 2017, 28, 213-222. [CrossRef]

212. Ma, X.; He, Z.; Li, L.; Liu, G.; Li, Q.; Yang, D.; Zhang, Y.; Li, N. Development and in vivo validation of tissue-engineered, small-diameter vascular grafts from decellularized aortae of fetal pigs and canine vascular endothelial cells. J. Cardiothorac. Surg. 2017, 12, 1-11. [CrossRef]

213. Li, N.; Sanyour, H.; Remund, T.; Kelly, P.; Hong, Z. Vascular extracellular matrix and fibroblasts-coculture directed differentiation of human mesenchymal stem cells toward smooth muscle-like cells for vascular tissue engineering. Mater. Sci. Eng. C 2018, 93, 61-69. [CrossRef]

214. Kong, X.; Kong, C.; Wen, S.; Shi, J. The use of heparin, bFGF, and VEGF 145 grafted acellular vascular scaffold in small diameter vascular graft. J. Biomed. Mater. Res. Part B Appl. Biomater. 2018, 107, 672-679. [CrossRef]

215. Filova, E.; Steinerova, M.; Travnickova, M.; Knitlova, J.; Musilkova, J.; Eckhardt, A.; Hadraba, D.; Matejka, R.; Prazak, S.; Stepanovska, J.; et al. Accelerated in vitro recellularization of decellularized porcine pericardium for cardiovascular grafts. Biomed. Mater. 2021, 16, 025024. [CrossRef]

216. Curtis, M.W.; Russell, B. Cardiac tissue engineering. J. Cardiovasc. Nurs. 2009, 24, 87. [CrossRef]

217. Melhem, M.R.; Park, J.; Knapp, L.; Reinkensmeyer, L.; Cvetkovic, C.; Flewellyn, J.; Lee, M.K.; Jensen, T.W.; Bashir, R.; Kong, H.; et al. 3D printed stem-cell-laden, micro-channeled hydrogel patch for the enhanced release of cell-secreting factors and treatment of myocardial infarctions. ACS Biomater. Sci. Eng. 2017, 3, 1980-1987. [CrossRef] 
218. Sun, Z.; Lee, S.-Y. A systematic review of 3-D printing in cardiovascular and cerebrovascular diseases. Anatol. J. Cardiol. 2017, 17, 423. [CrossRef]

219. Marieb, E.N.; Hoehn, K. Human Anatomy E Physiology; Pearson Education: San Francisco, CA, USA, 2007.

220. Zhang, Y.S.; Arneri, A.; Bersini, S.; Shin, S.-R.; Zhu, K.; Goli-Malekabadi, Z.; Aleman, J.; Colosi, C.; Busignani, F.; Dell'Erba, V.; et al. Bioprinting 3D microfibrous scaffolds for engineering endothelialized myocardium and heart-on-a-chip. Biomaterials 2016, 110, 45-59. [CrossRef]

221. Heng, B.C.; Haider, H.K.; Sim, E.K.W.; Cao, T.; Ng, S.C. Strategies for directing the differentiation of stem cells into the cardiomyogenic line age in vitro. Cardiovasc. Res. 2004, 62, 34-42. [CrossRef]

222. Jang, J.; Park, H.-J.; Kim, S.-W.; Kim, H.; Park, J.Y.; Na, S.J.; Kim, H.J.; Park, M.N.; Choi, S.H.; Park, S.H.; et al. 3D printed complex tissue construct using stem cell-laden decellularized extracellular matrix bioinks for cardiac repair. Biomaterials 2016, 112, 264-274. [CrossRef]

223. Gao, G.; Lee, J.H.; Jang, J.; Lee, D.H.; Kong, J.S.; Kim, B.S.; Choi, Y.J.; Jang, W.B.; Hong, Y.J.; Kwon, S.M.; et al. Tissue engineered bio-blood-vessels constructed using a tissue-specific bioink and 3D coaxial cell printing technique: A novel therapy for ischemic disease. Adv. Funct. Mater. 2017, 27, 1700798. [CrossRef]

224. Shin, Y.; Han, S.; Jeon, J.; Yamamoto, K.; Zervantonakis, I.; Sudo, R.; Kamm, R.D.; Chung, S. Microfluidic assay for simultaneous culture of multiple cell types on surfaces or within hydrogels. Nat. Protoc. 2012, 7, 1247-1259. [CrossRef] [PubMed]

225. Hinton, T.J.; Jallerat, Q.; Palchesko, R.N.; Park, J.H.; Grodzicki, M.S.; Shue, H.-J.; Ramadan, M.H.; Hudson, A.R.; Feinberg, A.W. Three-dimensional printing of complex biological structures by freeform reversible embedding of suspended hydrogels. Sci. Adv. 2015, 1, e1500758. [CrossRef] [PubMed]

226. Mastikhina, O.; Moon, B.-U.; Williams, K.; Hatkar, R.; Gustafson, D.; Mourad, O.; Sun, X.; Koo, M.; Lam, A.Y.; Sun, Y.; et al. Human cardiac fibrosis-on-a-chip model recapitulates disease hallmarks and can serve as a platform for drug testing. Biomaterials 2020, 233, 119741. [CrossRef] [PubMed]

227. Ott, H.C.; Matthiesen, T.S.; Goh, S.K.; Black, L.D.; Kren, S.M.; Netoff, T.I.; Taylor, D.A. Perfusion-decellularized matrix: Using na-ture's platform to engineer a bioartificial heart. Nat. Med. 2008, 14, 213-221. [CrossRef]

228. Li, Q.; Williams, C.G.; Sun, D.D.N.; Wang, J.; Leong, K.; Elisseeff, J.H. Photocrosslinkable polysaccharides based on chondroitin sulfate. J. Biomed. Mater. Res. 2003, 68A, 28-33. [CrossRef]

229. Nettles, D.L.; Vail, T.P.; Morgan, M.T.; Grinstaff, M.; Setton, L.A. Photocrosslinkable Hyaluronan as a Scaffold for Articular Cartilage Repair. Ann. Biomed. Eng. 2004, 32, 391-397. [CrossRef]

230. Vedadghavami, A.; Minooei, F.; Mohammadi, M.H.; Khetani, S.; Kolahchi, A.R.; Mashayekhan, S.; Sanati-Nezhad, A. Manufacturing of hydrogel biomaterials with controlled mechanical properties for tissue engineering applications. Acta Biomater. 2017, 62, 42-63. [CrossRef]

231. Cummings, C.L.; Gawlitta, D.; Nerem, R.M.; Stegemann, J.P. Properties of engineered vascular constructs made from collagen, fibrin, and collagen-fibrin mixtures. Biomaterials 2004, 25, 3699-3706. [CrossRef]

232. Hinderer, S.; Layland, S.L.; Schenke-Layland, K. ECM and ECM-like materials-Biomaterials for applications in regenerative medicine and cancer therapy. Adv. Drug Deliv. Rev. 2016, 97, 260-269. [CrossRef]

233. Johnson, K.A.; Rogers, G.J.; Roe, S.C.; Howlett, C.R.; Clayton, M.K.; Milthorpe, B.K.; Schindhelm, K. Nitrous acid pre-treatment of tendon xenografts cross-linked with glutaraldehyde and sterilized with gamma irradiation. Biomaterials 1999, 20, $1003-1015$. [CrossRef]

234. Roe, S.; Milthorpe, B.; True, K.; Rogers, G.; Schindhelm, K. The effect of gamma irradiation on a xenograft tendon bioprosthesis. Clin. Mater. 1992, 9, 149-154. [CrossRef]

235. Cheung, D.T.; Perelman, N.; Tong, D.; Nimni, M.E. The effect of gamma-irradiation on collagen molecules, isolated alpha-chains, and crosslinked native fibers. J. Biomed. Mater. Res. 1990, 24, 581-589. [CrossRef]

236. Möllers, S.; Heschel, I.; Damink, L.H.O.; Schügner, F.; Deumens, R.; Müller, B.; Bozkurt, A.; Nava, J.G.; Noth, J.; Brook, G.A. Cytocompatibility of a Novel, Longitudinally Microstructured Collagen Scaffold Intended for Nerve Tissue Repair. Tissue Eng. Part A 2009, 15, 461-472. [CrossRef]

237. Huang, N.; Yu, J.; Sievers, R.; Li, S.; Lee, R.J. Injectable Biopolymers Enhance Angiogenesis after Myocardial Infarction. Tissue Eng. 2005, 11, 1860-1866. [CrossRef]

238. Zaitseva, T.; Yang, G.; Dionyssiou, D.; Zamani, M.; Sawamura, S.; Yakubov, E.; Ferguson, J.; Hallett, R.L.; Fleischmann, D.; Paukshto, M.V.; et al. Delivery of hepatocyte growth factor mrna from nanofibrillar scaffolds in a pig model of peripheral arterial disease. Regen. Med. 2020, 15, 1761-1773. [CrossRef]

239. Hume, P.; He, J.; Haskins, K.; Anseth, K.S. Strategies to reduce dendritic cell activation through functional biomaterial design. Biomaterials 2012, 33, 3615-3625. [CrossRef]

240. Hume, P.S.; Anseth, K.S. Inducing local T cell apoptosis with anti-Fas-functionalized polymeric coatings fabricated via sur-faceinitiated photopolymerizations. Biomaterials 2010, 31, 3166-3174. [CrossRef]

241. Hume, P.S.; Bowman, C.N.; Anseth, K.S. Functionalized PEG hydrogels through reactive dip-coating for the formation of immunoactive barriers. Biomaterials 2011, 32, 6204-6212. [CrossRef]

242. Kristofik, N.J.; Qin, L.; Calabro, N.E.; Dimitrievska, S.; Li, G.; Tellides, G.; Niklason, L.E.; Kyriakides, T.R. Improving in vivo outcomes of decellularized vascular grafts via incorporation of a novel extracellular matrix. Biomaterials 2017, 141, 63-73. [CrossRef] 